Portland State University

PDXScholar

$11-19-2017$

\title{
Hydrostratigraphy of Warren Bench and Surrounding Area, Columbia County, Oregon
}

Eli Thomas Ahern

Portland State University

Follow this and additional works at: https://pdxscholar.library.pdx.edu/honorstheses

Let us know how access to this document benefits you.

\section{Recommended Citation}

Ahern, Eli Thomas, "Hydrostratigraphy of Warren Bench and Surrounding Area, Columbia County, Oregon" (2017). University Honors Theses. Paper 512.

https://doi.org/10.15760/honors.517

This Thesis is brought to you for free and open access. It has been accepted for inclusion in University Honors Theses by an authorized administrator of PDXScholar. Please contact us if we can make this document more accessible: pdxscholar@pdx.edu. 


\title{
Hydrostratigraphy of Warren Bench and Surrounding Area, Columbia County, Oregon
}

\author{
by \\ Eli Thomas Ahern \\ A thesis submitted in partial fulfillment of the \\ Requirements for University Honors
}

Bachelors of Science

in

Geology

Thesis Advisor:

Robert B. Perkins

Portland State University

2017 


\begin{abstract}
Areas of Columbia County in northwest Oregon, particularly along U.S. Route 30 directly north of the Portland Metro region, are projected to see significant increases in population. However, development in areas not currently supplied by municipalities drawing water from the Columbia River could be limited by availability of suitable water resources. This is a concern for the area immediately west and upslope from Highway 30 between the cities of Scappoose and Saint Helens, a relatively flat area locally known as the "Warren Bench" that seems otherwise well suited for development. Groundwater resources there, and indeed in most areas of the county, are poorly understood and locating reliable zones with consistent and potable groundwater yields has been a challenge for land owners and developers.

In this study I analyzed 391 water well reports from the Warren Bench and surrounding area that were downloaded from the Oregon Water Resources Department (OWRD) website. I extracted locations, lithologic descriptions and well yield data from these records and correlated this information with previously published maps and reports of the local surface geology in order to identify and characterize the major water-bearing zones.

The major water-bearing zones were separated into five physically distinct hydrostratagraphic units: the early Eocene Goble Volcanic Series, a tholeiitic and alkalic basalt; the mid to late Oligocene Pittsburg Bluff Formation, chiefly a fine-grained marine sandstone; the late Oligocene to early Miocene Scappoose Formation, typically arkosic sandstones interlayered with siltstone and shales; the lower to middle Miocene Grouse Creek, Ortley, Winter Water, and Sentinel Bluffs Members of the Grande Ronde Basalt; alluvial deposits from late Miocene through the Holocene include fluvial and lacustrine deposits of the late Miocene and Pliocene Sandy River Mudstone and Troutdale Formation, Pleistocene sand and silt deposits from the Missoula Floods which may include surficial loess deposits, and late Pleistocene and Holocene alluvium locally deposited in fluvial channels. Of these, the members of the Grande Ronde are on average the most productive; however, water-bearing zones in the Grande Ronde Basalt are generally confined between individual flows. Generally disconnected vertically, these discrete water-bearing zones vary between 1-15 meters in thickness. Therefore, wells completed in the Grande Ronde are often screened or open across several members in order to achieve optimal yield.

Typically, water wells that are screened through the Oligocene and early Miocene sedimentary formations contain high levels of dissolved solids (Wagner, 2013) and unpredictable yields. However, several wells penetrating to the lower Scappoose Formation have been completed in a conglomerate water-bearing zone with exceptionally high yields. This zone is laterally discontinuous and poorly constrained and described by Kelty (1981) as incised channels of clast-supported conglomerates. These channels appear to be part of the paleotopography developed on the Pittsburg Bluff Formation. The oldest sediments of the Scappoose Formation and first to be deposited within these incised channels have been correlated with early flows of the Columbia River Basalt Group.
\end{abstract}




\section{Acknowledgments}

First and foremost I would like to thank Columbia County and McNulty Water People's Utility District for funding this research. Secondly, I would like to thank my thesis advisor Dr. Robert Perkins. You have been a guiding light, a voice of reason, and an absolute inspiration through the entirety of this research project. You offered your invaluable experience and always provided sound guidance. With great patience you provided every resource to insure the success of this project.

I would also like to thank Michael Sawlan from the Menlo Park USGS office in California and Ray Wells from the USGS Oregon Water Science Center here in Portland for taking the time to discuss their geologic mapping of the Chapman quadrangle and for lending PSU a preliminary copy for reference on this project.

I also want to thank my family for their unconditional love and support, my friends who never ceased to forgive every time I declined an invite or canceled plans to work a weekend, long day, or late night. Most importantly, I want to thank Tina for all her encouragement, support, and understanding. Some of the best days working on this project were of you, Kyla, and me driving the back roads of Warren Bench, collecting samples in a torrential downpour, or hiking up creeks, or down the breathtaking access roads in search of bedrock.

Finally, I would like to thank the Portland State University Geology Department for providing a solid geologic background and rigorous training necessary to execute this project, and to the University Honors Collage for providing the avenue that made the undergraduate thesis possible for me. It has truly been a great honor to work on this project, and I can only hope the work we've done helps in meeting the ever-growing demand for sustainable water resource in our neighboring Columbia County. 


\section{Table of Contents}

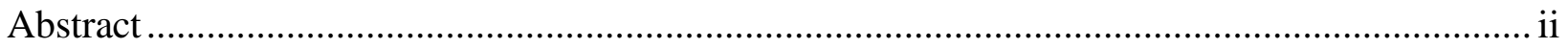

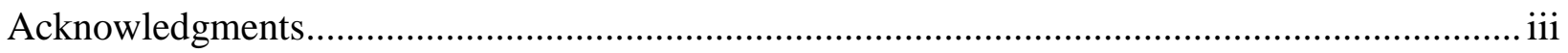

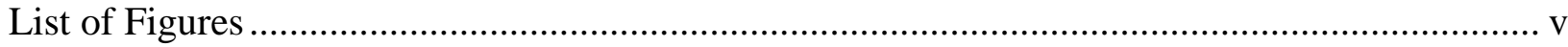

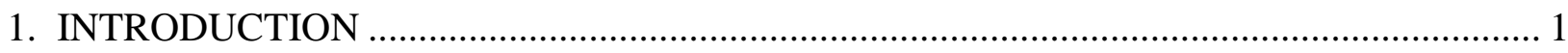

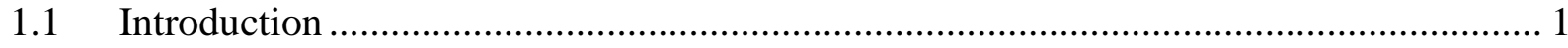

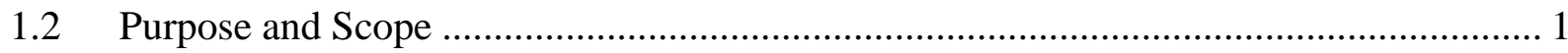

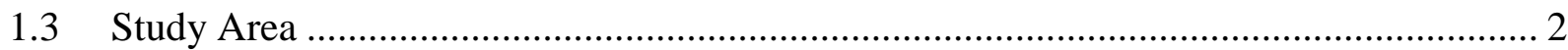

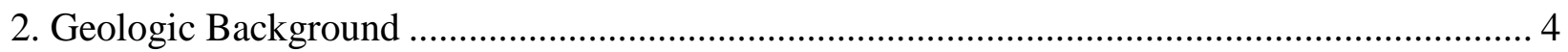

2.1 Regional Setting and General Geologic History ................................................... 4

2.2 Geologic Units in the Study Area ............................................................................ 7

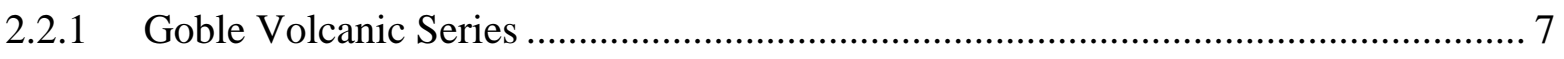

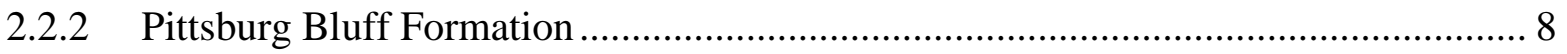

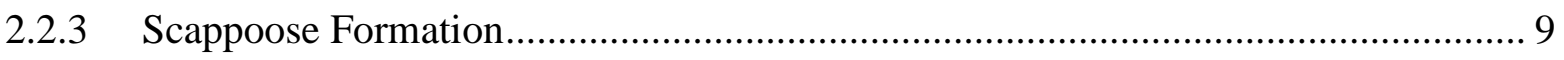

2.2.4 Columbia River Basalt Group ........................................................................ 10

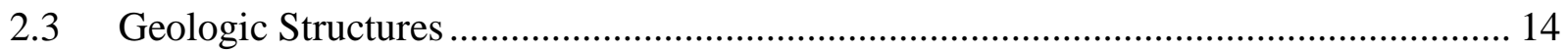

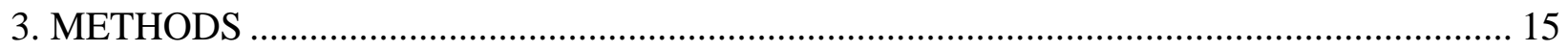

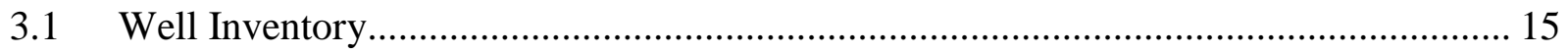

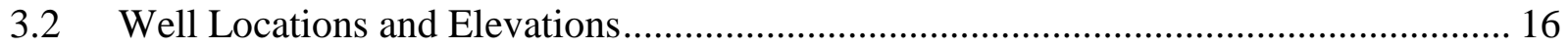

3.3 Determination of Lithology and Water-bearing Zones from Well Logs ..................... 22

3.4 Determination of Hydraulic Parameters for Wells and Water-bearing Units ............... 26

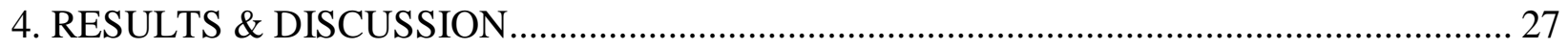

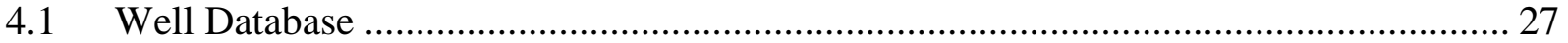

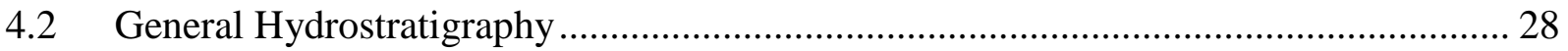

4.2.1 Goble Volcanic Series................................................................................... 28

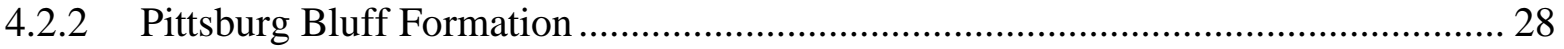

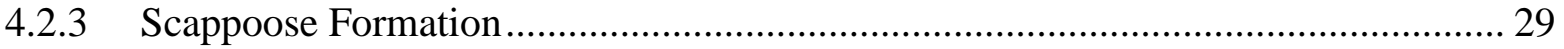

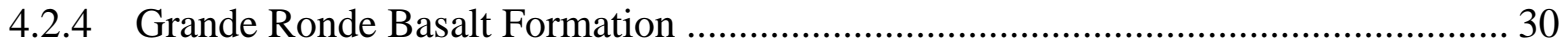

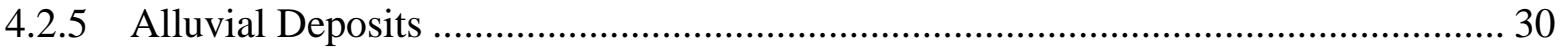

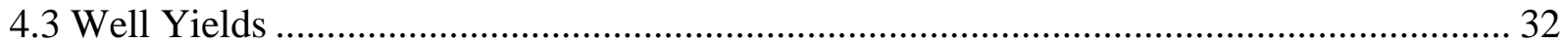

4.4 Static Water Level \& Depth to Water Maps ..................................................................... 34

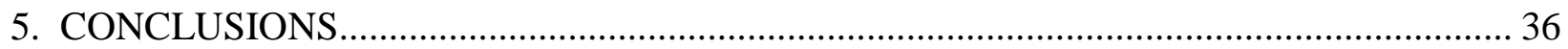

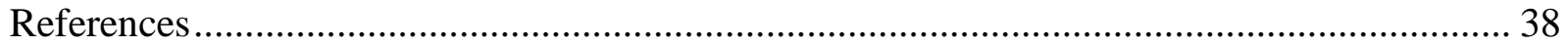

Digital Attachment 1. Warren Bench Water Well Database Spreadsheet ............................. 41

Appendix 1. Chemical Composition of Select Members of the Columbia River Basalts ........ 42

Appendix 2. Hydrogeologic Characteristics ............................................................... 43 


\section{List of Figures}

Figure 1. Regional Reference Map of the Study Area ...................................................... 2

Figure 2. Geography of Warren Bench and Surrounding Areas .......................................... 3

Figure 3. Generalized Geologic Map of Columbia County, Oregon....................................... 5

Figure 4. Stratigraphic Column and Nomenclature of CRBG Units of the Study...............13

Figure 5. Flood Basalt Column and Influence of Faults on Intra-Flow Zones (Tolan 2009)..... 15

Figure 6. Example of Satellite-Aerial Image Showing Tax Lot Information........................... 19

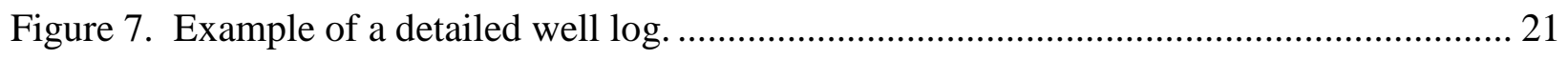

Figure 8. Preliminary Geologic Reference Map provided by (Wells et al.., 2017) .................. 22

Figure 9. Oregon Geologic Digital Compilation layer (Smith, 2015).................................. 25

Figure 10. Example of a Well Open Through Multiple Zones ............................................. 31

Figure 11. Well Yields in gallons per minute, domestic (blue) and public (red) wells............. 32

Figure 12 Well Yield and the Correlation of Structural Influence ........................................ 33

Figure 13. Well Bottom meters above sea-level, domestic (blue) and public (red) wells.......... 34

Figure 14. Preliminary Map of the Potentiometric Surface. Aquifers undifferentiated. ............ 35 


\section{INTRODUCTION}

\subsection{Introduction}

The area informally referred to as "Warren Bench" is located in southeastern Columbia County immediately west of U.S. Route 30 between the cities of Scappoose and St. Helens (Figure 1). The area is a topographic bench, roughly four and a half kilometers wide, that rises 75 meters from Scappoose Bay and the nearby Columbia River on the east side of U.S. Route 30 ( $<10$ meters in elevation) westward to the foothills of the Northern Oregon Coast Range. The unincorporated communities of Warren and McNulty are located on the Warren Bench.

The relatively flat expanse of the Warren Bench seems well suited for further development, particularly given its close proximity to Portland. Future development in the area is dependent on adequate water supplies, including groundwater resources. However, the regional geology is complex and poorly understood and there is a lack of published hydrogeological information for the area. To protect existing groundwater sources and to manage expected future growth along the U.S. Route 30 corridor, a better understanding of the area hydrogeology is essential.

\subsection{Purpose and Scope}

The purpose of this study is to identify and characterize the major water-bearing units and boundary conditions of the Warren Bench area. Exploratory drilling and geophysical surveys are prohibitively expensive. Therefore, the hydrogeologic framework of the area is here assessed through the collation of water well reports from previously constructed wells that have been filed with the Oregon Water Resources Department. These reports contain geographic and lithologic descriptions, well construction details, and measurements of groundwater levels and well yields. 
These data together with previously published maps and reports of the local surface geology were used to determine and characterize major hydrostratigraphic units. Knowledge of the hydrostratigraphy provides important information regarding groundwater occurrence and a framework from which to approach future groundwater flow modeling efforts and management decisions.

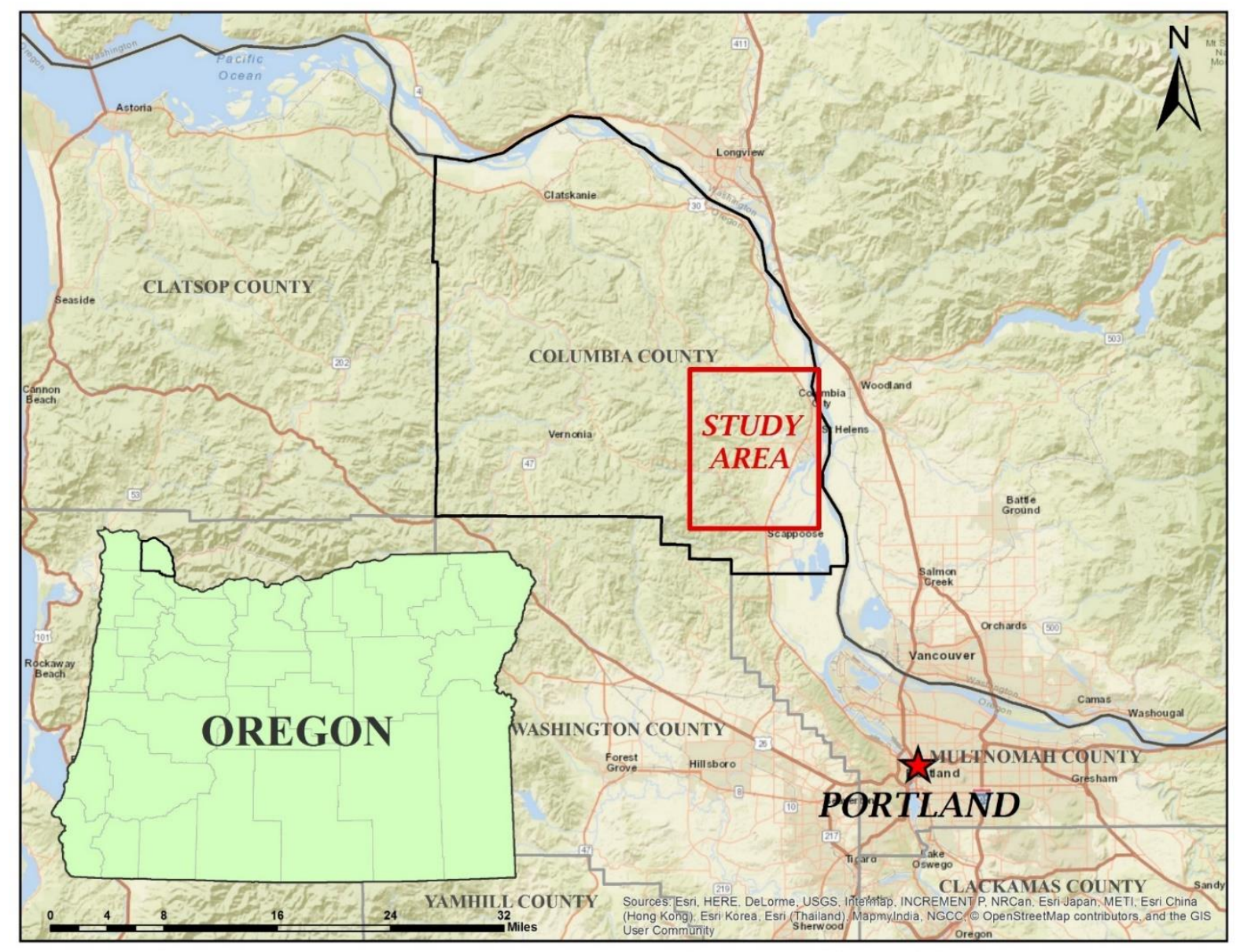

Figure 1. Regional Reference Map of the Study Area

\subsection{Study Area}

The study area is located in southeast Columbia County between the Columbia River and the eastern side of the Northern Oregon Coast Range. The study area encompasses a considerable expanse outside of the Warren Bench proper, including key parts of the recharge 
area contributing surface waters and groundwaters to Warren Bench and areas to the north and south that were included to better ascertain geologic trends or that lie within or adjacent to the McNulty Water District (Figure 2). The southwestern boundary of the study area is Alder Creek, which joins North Scappoose Creek in the town of Spitzenburg. Ten and a half kilometers west of Warren, and 636 meters at the summit, is Bunker Hill and the Clatskanie Divide, the local topographic high and headwaters of both Alder and Milton Creeks. The stretch of Milton Creek flowing to the northwest marks the western boundary of the study area. From the bend in Milton Creek and east to the City of Dear Island marks the northern boundary along Merrill Creek, adjacent to U.S. Route 30, the eastern boundary (Figure 2).

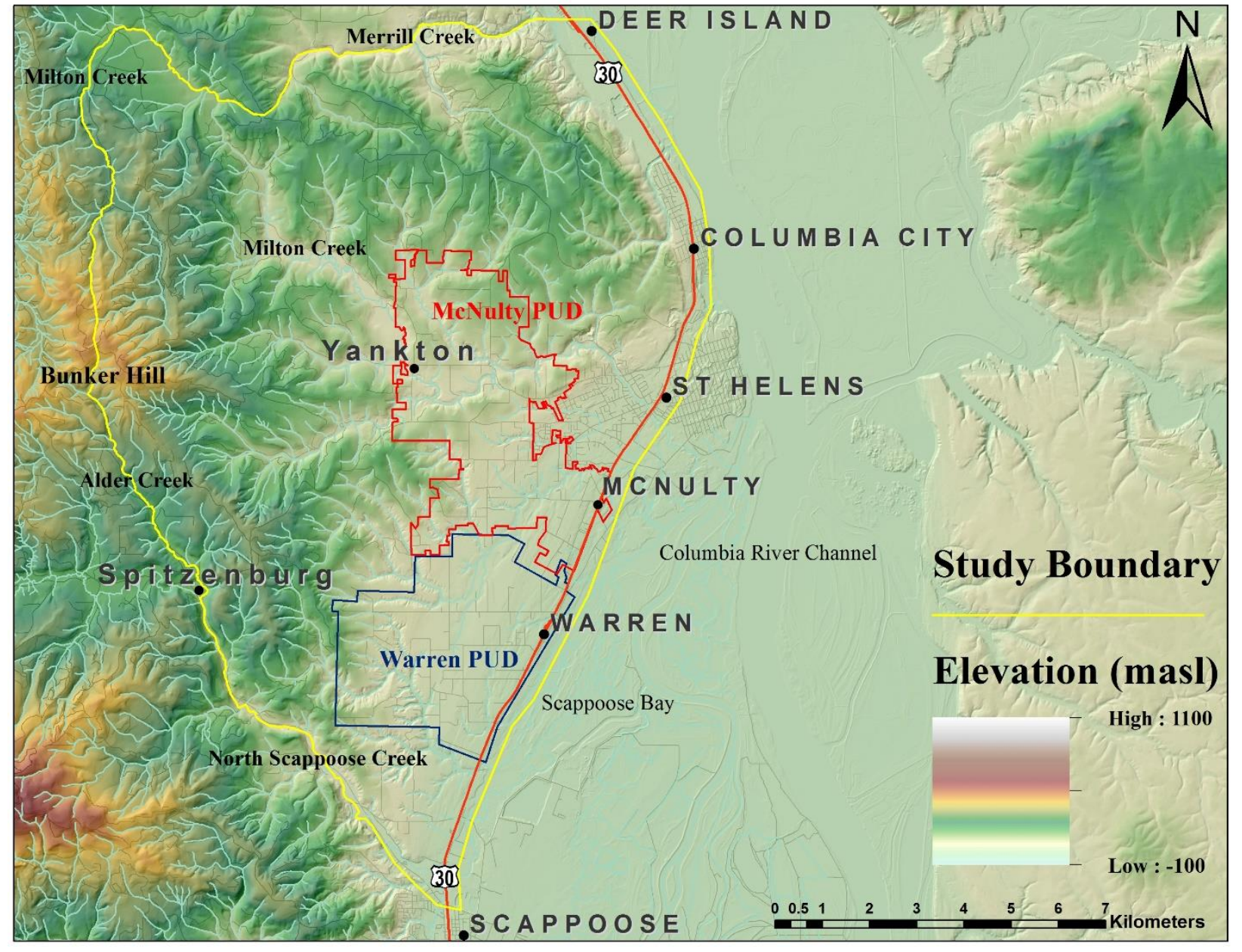

Figure 2. Geography of Warren Bench and Surrounding Areas 


\section{Geologic Background}

\subsection{Regional Setting and General Geologic History}

The Northern Oregon Coast Range is comprised of a complex assortment of Tertiary marine and volcanic strata deformed and segmented by regional warping and faulting (Figure 3). Throughout much of the early to middle Tertiary, the area now occupied by the Coast Range of western Oregon and Washington was an inundated basin underlain by tholeiitic and alkalic submarine and subaerial basalts of the Siletz River Volcanics. In early Eocene, a seamount chain on the Farallon plate "choked" the subduction zone, which at the time was near the position of the current Cascade arc, and caused a westward jump of the trench to the current offshore location of the Cascadia subduction zone. This was followed by extensive volcanism in the region which produced the middle to late Eocene Tillamook and Grays River Volcanics with local topographic highlands formed around primary eruptive centers (Wells et al., 2014). In the northern portion of the study area, similar late Eocene Goble Volcanics are present (Evarts, 2002, 2004), which Wells (2014) includes with the Grays River Volcanics. McPhee et al. (2014) treat these units together with the Siletz River Volcanics as the basement assemblage.

These basement volcanics and, in some areas nearby this study, late Eocene marine to deltaic sediments, including mudstones and siltstones of the Cowlitz and Keasey formations, were overlain by sediments of the Oligocene Pittsburg Bluff Formation, predominantly fine- to coarse-grained tuffaceous and micaceous arkosic sandstones, siltstones and mudstones (Eriksson, 2002; Evarts, 2002). Ongoing subduction from the late Eocene onward caused the uplift of the Coast Range as an asymmetric structural arch, resulting in a gentle eastward regional dip of basement volcanics and overlying sedimentary units east of the arch (Wells et al., 1994). 


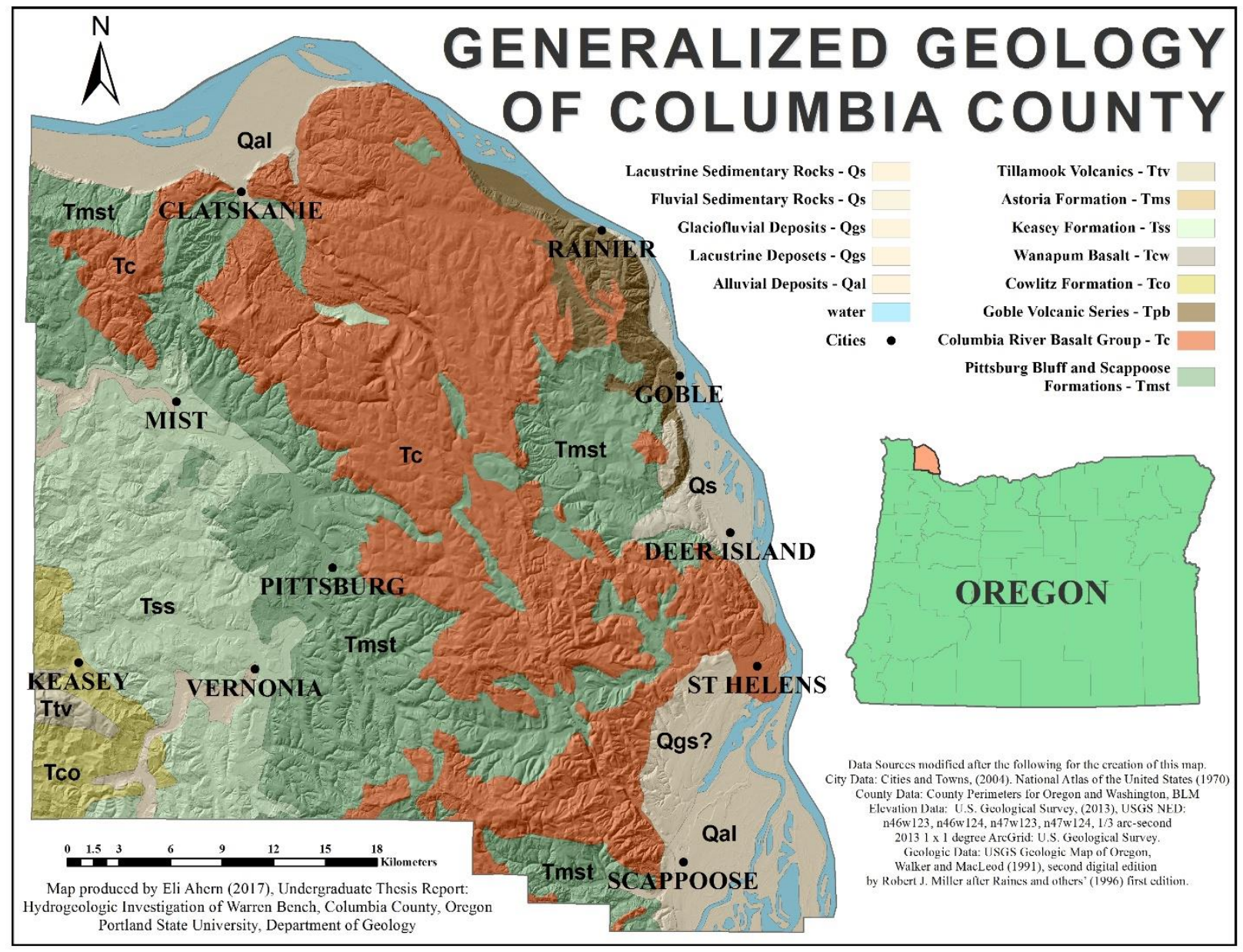

Figure 3. Generalized Geologic Map of Columbia County, Oregon.

Intended for general reference in this report and a regional geologic perspective. The surface geology was first published by the USGS in 1991 and has been refined with higher resolution since. As indicated in the legend, the Pittsburg Bluff and Scappoose Formations are undifferentiated as are the various members of the Columbia River Basalt. The Troutdale and Sandy River Mudstone Formations are assigned within Lacustrine and Fluvial Sedimentary Rocks.

Clockwise rotation of crustal components resulting from the oblique subduction of the Juan de Fuca plate created a series of northwest-trending folds and sub-parallel northweststriking faults superimposed on this eastward regional dip (Wells et al., 1994; Wells et al., 1998; Wells et al., 2014). The Portland Basin, one of several topographic and structural depressions that collectively constitute the Puget-Willamette forearc trough of the Cascadia subduction system, began to form during the early Miocene, after 20 Ma (Evarts et al., 2009). 
After a period of erosion, the Oligocene sediments of the Pittsburg Bluff Formation had developed into an irregular surface of moderate topographic relief (up to $245 \mathrm{~m}$; Van Atta and Kelty, 1985) with well-developed fluvial channels (Kelty, 1981). Sediments of the Scappoose Formation began to be deposited in lowland areas and fluvial channels atop late Oligocene sediments (Kelty, 1981). Scappoose sediments were then deposited atop late Oligocene sediments in shallow marine, deltaic and fluvial environments as indicated by marine fossils and mudstones, crossbedding and conglomerate units, and the presence of coal and plant materials (Kelty, 1981). Some conglomerate units within the Scappoose Formation contain material from the earliest Columbia River Basalts transported west by the ancestral Columbia River. Palagonitic sediments in the upper part of the formation are intercalated with Grande Ronde Basalt at many localities indicating that the Scappoose is largely coeval with early Columbia River Basalt Group (CRBG) volcanism (Van Atta and Kelty, 1985).

Following channels of the ancestral Columbia River, the first Columbia River Basalt flows, erupted from fissures in southeastern Washington and nearby areas of Oregon and Idaho, filled canyons, covered areas of low relief, and dammed seaward waterways (Beeson, 1989; Tolan et al., 2009). Successive flows of the Columbia River Flood Basalt continued to fill the subsiding Portland Basin displacing the ancestral Columbia River (Figure 3). In the study area, Evarts (2002a, 2004) identified four members of the CRBG Grande Ronde Basalt: the Wapshilla Ridge, the Ortley, Winter Water, and Sentinel Bluffs members. The most widespread and voluminous unit in the area is the Sentinel Bluffs Member, which is also the youngest unit (15.6 Ma; Tolan et al., 2009).

Folding of the Grande Ronde units, as in a well-developed NW-striking, SE-plunging syncline whose axis cuts through the study area and parallels Milton Creek, clearly indicates 
post-CRBG uplift and deformation, concomitant with further development of the Portland Basin (Evarts, 2002b, 2004). Fluvial and lacustrine deposits of the Sandy River Mudstone and Troutdale Formation filled the still subsiding Portland Basin throughout the late Miocene and Pliocene and overlie Grande Ronde Basalt in the lower elevations of the study area, although these have been locally excavated in some areas by subsequent downcutting of the Columbia River (Evarts, 2002a, 2004).

Pleistocene cataclysmic Missoula Floods deposited silts and sands in the area that locally mantle the older units between 60 and $75 \mathrm{~m}$ and potentially up to $105 \mathrm{~m}$ elevation. Much of the gentle upland surfaces are also mantled by several meters of Pleistocene loess deposits derived from the Columbia River floodplain (Evarts, 2002a). Finally, late Pleistocene and Holocene alluvium was locally deposited in fluvial channels. These include up to $70 \mathrm{~m}$ of material deposited by the Columbia River and its tributaries as sea level rose from its last-glacial lowstand as well as more recent deposits, generally silts and sands, deposited in the Columbia River floodplain (Evarts, 2004).

\subsection{Geologic Units in the Study Area}

\subsubsection{Goble Volcanic Series}

The upper Eocene to lower Oligocene Goble Volcanic Series was originally proposed by Wilkinson et al. (1946) for a thick section of dark gray platy basalt flows interfingered with massive pyroclastics of uniform texture and minor sediments exposed in the vicinity of Goble, Oregon, $20 \mathrm{~km}$ north of St. Helens. Surface outcrops extend from the Town of Deer Island just north of St. Helens to Walker Island, downstream of Rainier, Oregon. A total thickness of more 
than 1500 meters of Goble Volcanics occur between Kelso and Woodland, Washington on the east side of the Columbia River. Goble Volcanics were tentatively identified $~ 20 \mathrm{~km}$ south of Scappoose by the Richfield Oil Company along the crest of the Portland Hills at a depth of 640 $\mathrm{m}$; the well continued through $1700 \mathrm{~m}$ of this section of basalt, tuffs and breccias, before being terminated (Wilkinson et al., 1946).

The lower part of the series is predominantly basalt flows with associated flow breccia; however, tuff breccia occurs in the lowest sections interbedded with marine sandstone assigned to the marine Cowlitz Formation. The upper part of the series is comprised of basaltic flows along with significant amounts of associated pyroclastics, which range from 3-10 $\mathrm{m}$ in thickness (Evarts, 2002a).

\subsubsection{Pittsburg Bluff Formation}

The Pittsburg Bluff Formation is a sedimentary unit deposited in shallow marine to subaerial environments (Evarts, 2004). Only occurring in northwestern Oregon, the Pittsburg Bluff was first assigned as middle Oligocene by J.S. Diller in 1896 based on 10 distinct fossil mollusks he had collected from the banks along the Nehalem River near Pittsburg, Oregon (Moore, 1976). Most outcrops are located within the Vernonia and Forest Grove 15-min quadrangles though the Pittsburg Bluff Formation has been identified in a roadcut along the Vernonia-Scappoose Road within 3 kilometers of The Chapman School (Moore, 1976) and within the extent of this study.

At the type location along the Nehalem River, the Pittsburg Bluff Formation has been measured to a maximum known thickness of 200 meters. The lower 30 meters of the Pittsburg Bluff is a massive, olive-gray, fine-grained sandstone to siltstone that conformably overlies the 
Keasey Formation. The middle section consists of thinly bedded, light to olive gray, fine-grained sandstone and siltstone with foreset beds that can contain coal beds near the top. The upper 90 meters is a massive, friable, olive gray, fine-grained sandstone.

\subsubsection{Scappoose Formation}

Originally distinguished only by respective paleoflora and fauna, mineralogical differences in the Pittsburg Bluff Formation and overlying Scappoose Formation were identified by Van Atta (1971). Generally the Scappoose Formation is more abundant in lithic fragments and quartz than the underlying Pittsburg Bluff Formation (Kelty, 1981). The unconformable contact between these units is locally marked by a basaltic conglomerate or matrix supported pebble mudstone at the base of the Scappoose Formation (Van Atta, 1971; Van Atta and Kelty, 1985). Van Atta (1971) reported this conglomerate to be six or more feet thick with a sandy matrix at an outcrop located 1.5 miles north of Buxton Oregon but noted that it appeared interfingered with non-indurated sand stringers and lenses at another location some miles north and to pinch out towards the south. Niem and Van Atta (1973) describe the Scappoose Formation as having a deltaic origin based on carbonized wood and other plant debris identified in many outcrops.

The Scappoose Formation is informally divided into three zones (Van Atta, 1971). Above the basal conglomeritic zone, the lower Scappoose is yellowish-brown when weathered, and predominantly an arkosic silty sandstone occurring in a series of 4 to 8 feet thick beds estimated by Van Atta to have an aggregated thickness of "at least 200 feet". These beds tend to be loose to moderately indurated and could be calcareous or contain calcareous concretions. Dark gray tuffaceous and laminated mudstones up to 20 feet thick are also reported for the lower Scappoose (Van Atta, 1971). The upper unit is reported to be a brown to multicolored sandstone by 
(Wagner, 2013) and separated from the middle unit by a distinct blue clay layer. The Scappoose Formation is marked by localized channelization, latterly disconnected conglomerates, and the earliest flows of the Grande Ronde Basalts to reach the area.

\subsubsection{Columbia River Basalt Group}

\subsubsection{Grande Ronde Basalt}

The name Columbia River Basalt was first used by Russell in 1893 describing extensive lavas throughout Oregon, Washington, Idaho, and California and later constrained to those of Miocene age (Wilkinson, et al., 1946). The bulk of the Columbia River Basalt in western Oregon and throughout much of the Columbia Plateau is comprised of various flows belonging to the Grande Ronde Basalt Formation. Erupted from fissures in Southeastern Washington and adjacent areas of Oregon and Idaho between 16.5 and 15.6Ma., the earliest flows filled channels of the ancestral Columbia River and covered large areas of low relief (Tolan et al., 2009).

Three members of the Grande Ronde Basalt are mapped within the study area as chemically confirmed by Wells et al. (2017) in a pending publication of the greater Portland metropolitan area and Evarts (2004, 2002a) during the mapping of the Deer Island and St Helens 7.5' quadrangle. The most widespread is the Sentinel Bluffs Member. This unit is underlain by the Winter Water and Ortley members, all middle to upper-lower Miocene in age (Figure 4).

Elevations below 65 meters have been scoured of surficial sedimentary deposits by the latest glacier-outburst floods which exposed the Grande Ronde Basalt units along U.S. Route 30 at the northern end of St Helens and Columbia City (Evarts, 2004). At the surface, throughout the study area these basalts have been heavily weathered to laterites where all primary rock textures have been destroyed and closely resemble thoroughly weathered fine-grained sedimentary rocks (Evarts, 2004). 
The Sentinel Bluffs Member is the most widespread of the Columbia River Basalt units in the study area. In general, the upper 30 meters or more is heavily weathered to a reddishbrown laterite with fresh outcrops only located in creek beds, rock quarries, and along U.S. Route 30 north of St Helens (Evarts, 2004). It is distinguished by relatively high $\mathrm{MgO}$ at $4.5 \%$ and is a basaltic andesite averaging $54.3 \% \mathrm{SiO}_{2}, 2 \% \mathrm{TiO}_{2}, 11.4 \% \mathrm{FeO}, 0.34 \% \mathrm{P}_{2} \mathrm{O}_{5}$ and normal magnetic polarity (Evarts, 2002a; Madin and Newindrop, 2008) It is dark gray or black when fresh with sparse plagioclase phynocrysts up to $10 \mathrm{~mm}$. The upper section is highly vesicular and deeply weathered to a reddish brown and overlain by a thin .7 to 1.5 meter deposit of tan, medium-grained micaceous quartz claystone or sandstone correlated to the Vantage Member of the Ellensburg Formation (Swanson, 1979; Madin and Newindrop, 2008). Within the study area are multiple flows distinguished by highly vesiculated flow tops and reddish brown weathering horizons.

Underlying the Sentinel Bluffs is the Winter Water member. A glassy, fine-grained basaltic andesite only exposed in creek beds within the study area. Consisting of two individual flows as reported by Reidel et al. (1989), the basalt is phyric to abundantly phyric with plagioclase glomerocrysts $(<3 \mathrm{~mm})$, averaging $56.3 \% \mathrm{SiO}_{2}, 11.1 \% \mathrm{FeO}, 2.19 \% \mathrm{TiO}_{2}, 3.38 \%$ $\mathrm{MgO}$, and $0.37 \% \mathrm{P}_{2} \mathrm{O}_{5}$ (Madin, 2008). When fresh, the Winter Water basalt is medium light gray to gray (Wagner, 2013).

The Ortley member underlies the Winter Water member. It is easily confused with the older Grouse Creek member, although the two may be readily distinguished via magnetic polarity measurements (Reidel et al., 1989; Appendix 1.). The thickness of Ortley member varies significantly due to pre-Grande Ronde topography and could contain as many as 6 individual flows as reported by Reidel et al. (1989)( Appendix 1.). North of St Helens, 25 meters of the 
Ortley is exposed along U.S. Route 30. Further north in the Deer Island 7.5' quadrangle the Ortley is estimated to be at least 60 meters thick (Evarts, 2004).

The Ortley is a glassy to fine-grained, aphyric, basaltic andesite (Reidel et al., 1989; Appendix 1.). When fresh it is black and when weathered has been described by Wagner (2013) to be blue or green. Most samples have $\mathrm{MgO}$ ranging between 3.0 and $4.3 \%$ and $\mathrm{TiO} 2$ between 1.8 and $2.4 \%$, averaging $57.7 \% \mathrm{SiO}_{2}, 10.8 \% \mathrm{FeO}, \mathrm{TiO}_{2} 1.99 \%, \mathrm{MgO} 3.4 \%$, and $\mathrm{P}_{2} \mathrm{O}_{5} 0.35 \%$ (Reidel et al., 1989; Appendix 1.). The variation is presumed due to leaching of mobile elements of $\mathrm{P}_{2} \mathrm{O}_{5}$ and $\mathrm{MgO}$ while enriching $\mathrm{SiO}_{2} \mathrm{TiO}_{2}$ (Madin and Newindrop, 2008).

\subsubsection{Wanapum Basalt}

A fourth Columbia River Basalt unit, the basalt of Sand Hollow, Member of Frenchman Springs of the Wanapum Basalt Formation is mapped along the Clatskanie Divide to the west (Figure 8) (Wells et al., 2017) and south around the rim of Dutch Canyon identified in the Dixie Mountain 7.5' quadrangle mapped by Madin and Clark (2007). Following the Vantage hiatus, eruptions of the Wanapum Basalt covered areas of low relief and portions of the Grande Ronde. The basalt of Sand Hollow is black when fresh with sparse amounts of plagioclase phenocrysts. When weathered, the basalt is dark or greenish gray. It has a relatively high iron content, averaging $13.9 \% \mathrm{FeO}, 50.9 \% \mathrm{SiO}_{2}, 2.96 \% \mathrm{TiO}_{2}$, and $0.57 \% \mathrm{P}_{2} \mathrm{O}_{5}$ (Madin and Newindrop, 2008). 


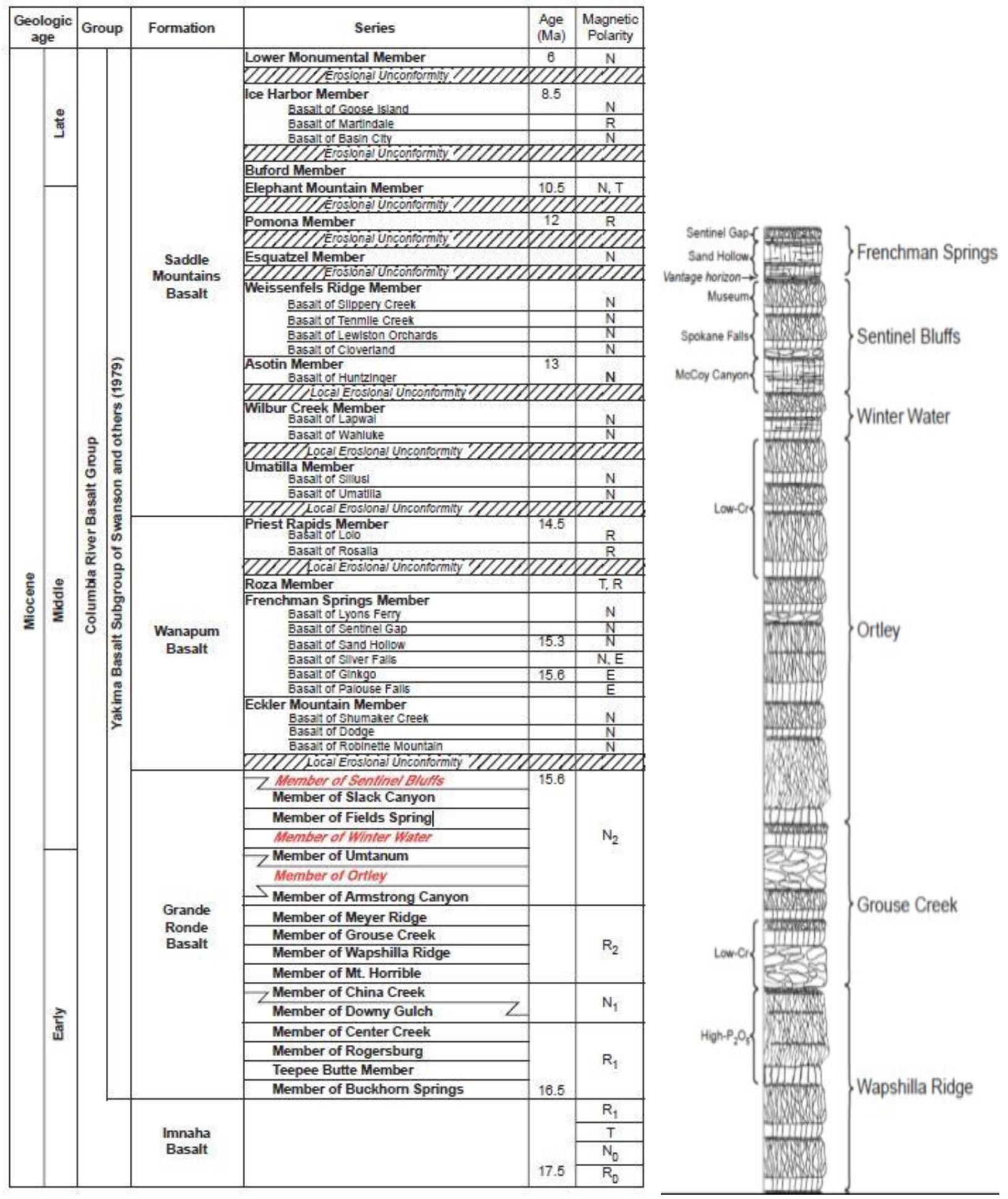

Figure 4. Left: Nomenclature of the CRBG's (Reidel et al., 1989); Right: Stratigraphic Column of CRBG Units of the Study (Wells, 2009) 


\subsection{Geologic Structures}

Many geologic structures have been mapped within the study area, however most are inferred in the absence of conclusive evidence. Strike and dip measurements north of St Helens were first taken by Wilkinson et al. (1946) in the exposed beds of the Grande Ronde. These were uniformly dipping to the south toward Warren Bench at roughly $2^{\circ}$ while 2 kilometers northwest of Scappoose these same beds were measured with a $4^{\circ}$ dip to the north. A subtle fold axis has been mapped trending to the southeast near the town of Warren (Evarts, 2004). Wells et al., (2017) have projected the axis of the syncline to the northwest before turning west near the town of Yankton.

Faults have largely been inferred by Evarts (2002a, 2004) and Wilkinson et al. (1946). Lacking conclusive evidence because of deep weathering of the bedrock and limited outcrop at the surface, Wilkinson et al. (1946) suggest the possibility of a large fault striking northwest from Scappoose. They state as evidence the straightness of North Scappoose and Alder Creeks, the marked differences in altitude of adjacent deposits, and a northwest topographic trend passing beyond Bunker Hill, though they concede that no conclusive evidence was obtained and that pre-depositional environment (paleotopography) and subsequent intracanyon flows could result in the same physiographic features. 


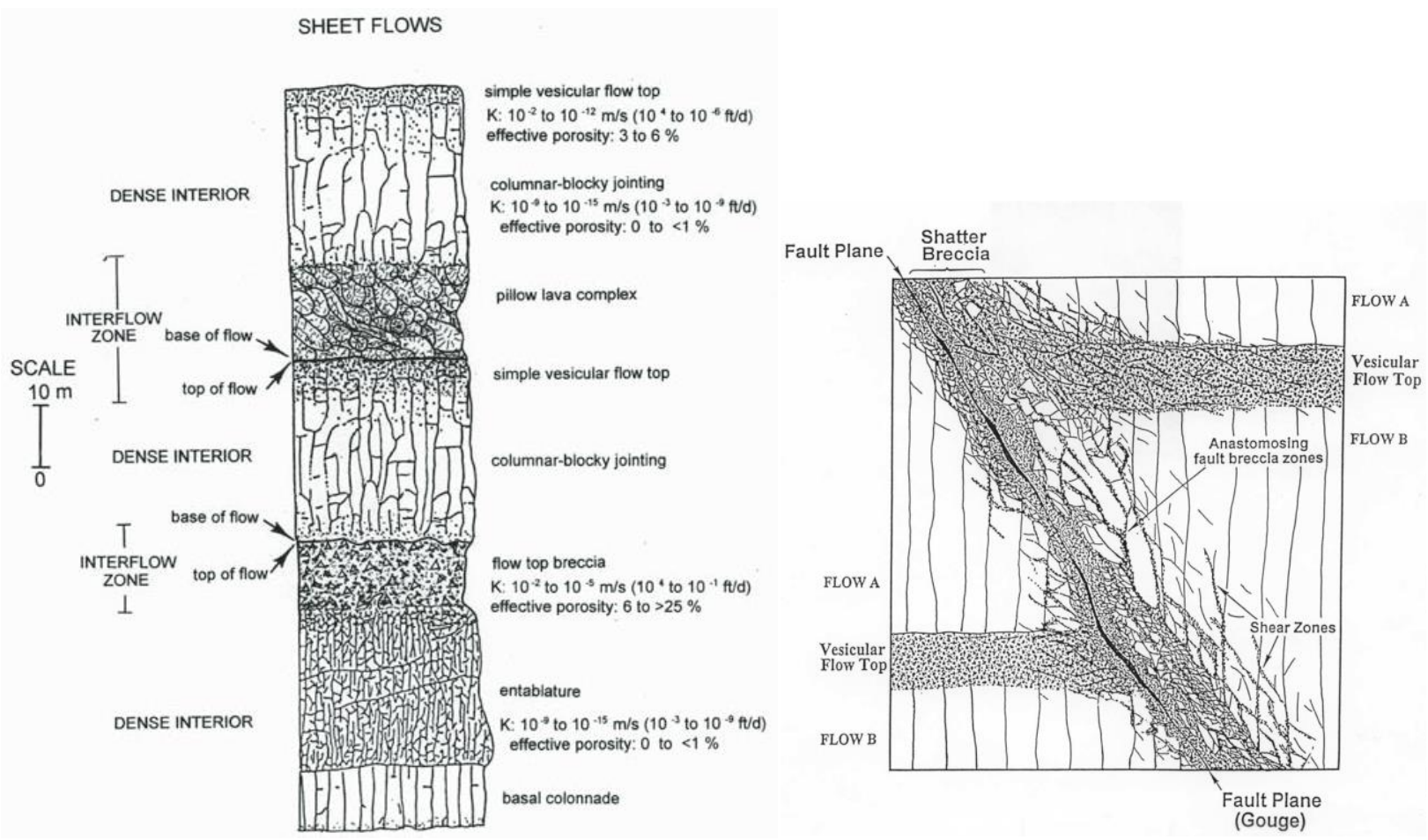

Figure 5. Flood Basalt Column and Influence of Faults on Intra-Flow Zones (Tolan et al., 2009).

\section{METHODS}

\subsection{Well Inventory}

Water well reports ("well logs") for all wells in the study area, dated through March2017, were downloaded from the Oregon Water Resources Department website and pertinent information from these reports manually entered into an Excel database for this study. Available water well reports were found by querying the township-range-sections (Oregon Water Resources Department, 2017) encompassing the study area (Table 1).

Not all logs in the furthest reaches beyond Warren Bench and McNulty Water District were added to the inventory but all water well reports for the Warren Bench area, the stretch of North Scappoose Creek extending northwest to Bunker Hill and east to Columbia City, and those extending two miles beyond McNulty in all directions were included. This excludes a large 
portion of rural wells from the pre-1960's city of St. Helens which were given Lot \# and street addresses no longer correlative to the modern development within the city and are now largely served by municipal water service.

Water well reports of the deepest and most recent wells were located and entered in the database from as far north as Deer Island along Merrell Creek and west to the Clatskanie Divide. The area trending northwest along Milton Creek was heavily sampled but only the deepest and most recent well reports from the furthest reaches beyond two miles of McNulty's water district were included. Major municipal wells along U.S. Route 30 north of St Helens to Deer Island were also included.

Table 1. Public Land Survey Township-Range \& Sections Encompassing Study Area

\begin{tabular}{llll} 
Township & Range & \multicolumn{1}{c}{ Sections Fully Sampled } & \multicolumn{1}{c}{ Sections Partially Sampled } \\
\hline $3 \mathrm{~N}$ & $2 \mathrm{~W}$ & & $1,2,12$ \\
$4 \mathrm{~N}$ & $1 \mathrm{~W}$ & $6-8,17-19,30$ & 5 \\
$4 \mathrm{~N}$ & $2 \mathrm{~W}$ & $1-3,10-16,22-27,35-36$ & $4,9,17,21,28,34$ \\
$5 \mathrm{~N}$ & $1 \mathrm{~W}$ & $19,30-32$ & $7-8,17-18,20-21,28-29,33$ \\
$5 \mathrm{~N}$ & 2W & $23-27,34-36$ & $9-17,20-22,28-29,32-33$
\end{tabular}

\subsection{Well Locations and Elevations}

Accurate geographic locations and surface elevations of wellheads are imperative in interpreting the area hydrostratigraphy and in identifying structural deformation, including plausible faulting. Well reports have historically included fields for the site address, tax lot, township and range, section, and quarter-quarter section (Oregon Water Resource Department, 2017). Oregon Water Well Report forms were updated in 2010 to include latitude and longitude as handheld GPS units became more readily available. Some well logs included a map 
identifying the physical location of the well on the property either as a sketch or with satellite imagery.

When inputting a well location into the database, the address was first located using Google Earth. ArcGIS was used to create a map including satellite-aerial imagery, tax lots, and sections, for reference (Figure 6). Once the address was confirmed, an attempt was made to pinpoint the well location on the property. If a small structure (e.g., $\sim 1 \times 1 \mathrm{~m}$ ) was identified in close proximity (up to $40 \mathrm{~m}$ ) to a house in satellite-aerial imagery, it was assumed to be a well house. If a well house was not identified in the imagery, the well was assumed to be immediately adjacent to the house, typically on the upslope side (i.e., generally within $15 \mathrm{~m}$ from the center of the house). Geographic coordinates and the elevation were recorded from Google Earth.

To ensure a sizable dataset for analysis, all well logs with useful hydrogeologic information were included in the database regardless of completeness. A locator score was assigned to each well entry to indicate the reliability of the location, based on the following criteria (summarized in Table 2). In most well logs the driller did not record all of the geographic information and in some logs the information was conflicting. Prior to 1980 the area was still rural and many of the well logs provided a Rural Route and Box number that could not be identified using Google Earth. If a given well log did not provide a tax lot and quarter/quarter section, the well could not be located. If no other useful information (e.g., screen depth, lithology, etc.) was available, these logs were discarded ( 15-20 logs in total); otherwise, if the $\log$ did provide information deemed to be useful, the log was entered into the Excel database but with a locator score of 1 , indicating no reliable location available and without coordinates.

Many of the wells drilled prior to 2000 had recorded a quarter/quarter section that did not agree with the provided address or available tax lot numbers; in some cases there were not even 
roads or houses in the given quarter-quarter section. In these cases, the address was used to locate the well. In other cases, there were multiple well logs with the same tax lot but conflicting addresses, or conflicting tax lots with the same address. If it were conflicting tax lots, the address was used to locate the well, and if it were conflicting addresses, the tax lot was used to locate the well. These conflicts were assumed to be the result of subdivided property, or rural areas that had been developed and rural routes updated with road names.

Many of the logs with questionable location information were later updated in the database after the dataset was mapped in ArcGIS. In cases where multiple logs had been assigned a single tax lot and or address, the dates of the logs and listed names of owners were referenced; if both logs had been filed within a year under different owners, it was assumed the original lot had been subdivided and an attempt was made to assign a well location based on sequential lot numbers and downgraded in location score to reflect that only the address or tax lot was used in the location process. This was common across Warren Bench and areas of low relief during the booming residential development of the late 90's and through the turn of the century. During this time, previously zoned forest or agricultural land was being subdivided into 2-5 acre lots at a rate obviously ahead of government offices' abilities to keep pace with formal tax lots assignments. This is likely the case for $\sim 20$ wells in the Warren Bench and Milton Creek areas (Figure 6). 


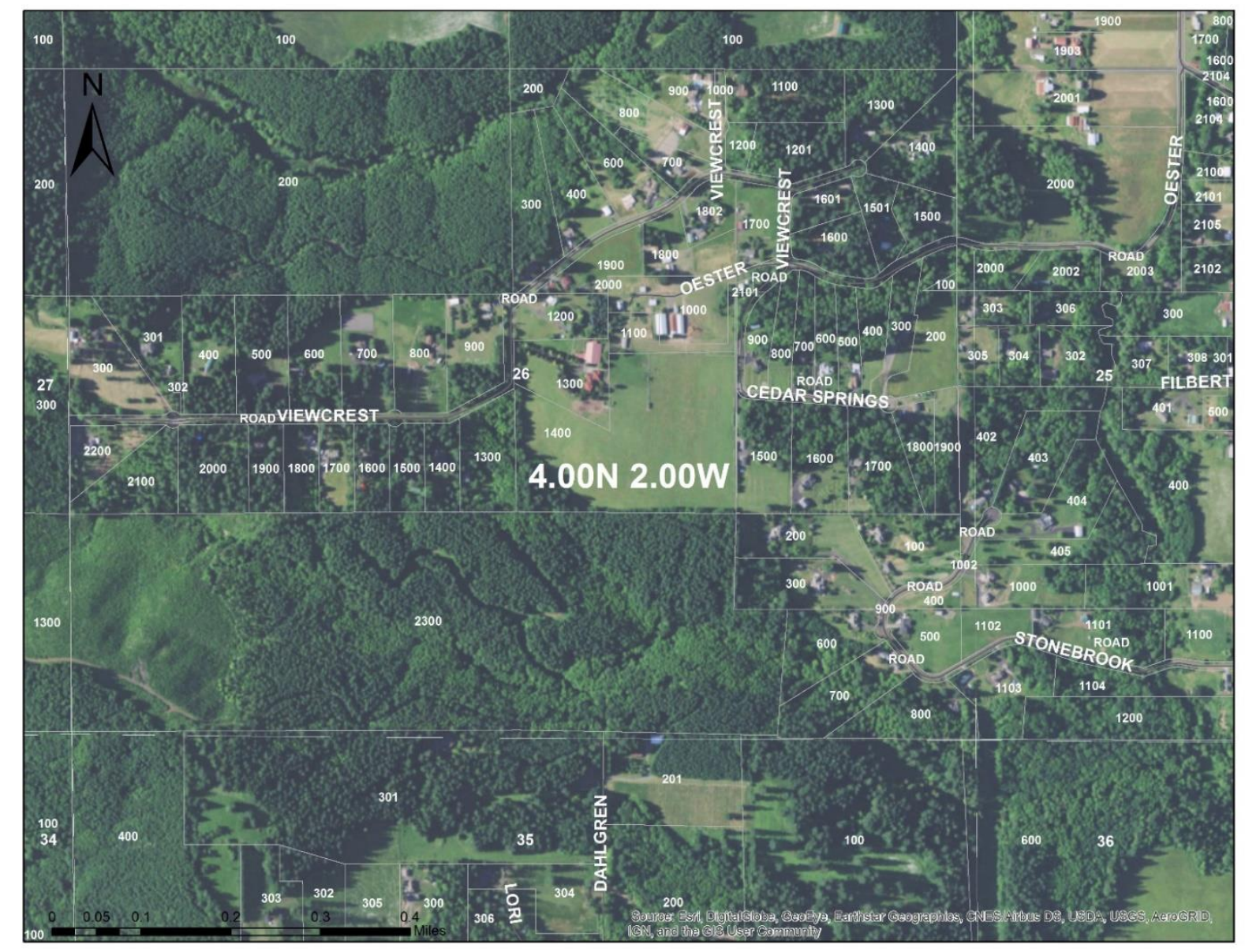

Figure 6. Example of Satellite-Aerial Image Showing Tax Lot Information.

Common to Warren Bench and within the sampled area, at least 32 wells had been deepened one or more times, as indicated by selection of the "Alteration" or "Deepening" boxes (vs the "New" box) on the well report. Of these, 21 well logs recorded the deepening of previously existing wells, and 3 of those were deepening of previously deepened wells. Throughout the study area, an additional 23 well logs were found to be located within the same tax lot. Nine of these were relocated by tax lot and section. The remaining 14 were lowered in score as the other logs proved to be more readily correlated with nearby logs. Furthermore, if two well reports shared the same address and tax lot, but the reports did not explicitly indicate that a previous well had been deepened, it was assumed that two wells existed within the tax lot. 
Well locations were not field-verified. When neither GPS coordinates nor a location map of the wellhead were included with a well $\log$, the log entry was assigned a locator score partially based on the variation of elevation across the property. As the location was presumed on satellite-aerial imagery, surface relief was measured using Google Earth at a distance of approximately 100 meters in all directions of the house. In general: property that was located in a valley has variation in elevation of less than 3 meters; property that was located on a hill has variation in elevation of 3-10 meters; and property located on a ridge has variation in elevation to exceed 10 meters (Table 2).

\section{Table 2. Water Well Locator Score Criteria}

(10) GPS Coordinates

(9) Location Map with Address and Tax Lot

(8) Address and Tax Lot with elevation change $<3$ meters

(7) Address and Tax Lot with elevation change $=3-10$ meters

(6) Address and Tax Lot with elevation change $>10$ meters

(5) Address or Tax Lot with elevation change $<3$ meters

(4) Address or Tax Lot with elevation change $=3-7$ meters

(3) Address or Tax Lot with elevation change > 7 meters

(2) Address and Tax Lot Mismatch

(1) No Reliable Data to Locate Well 


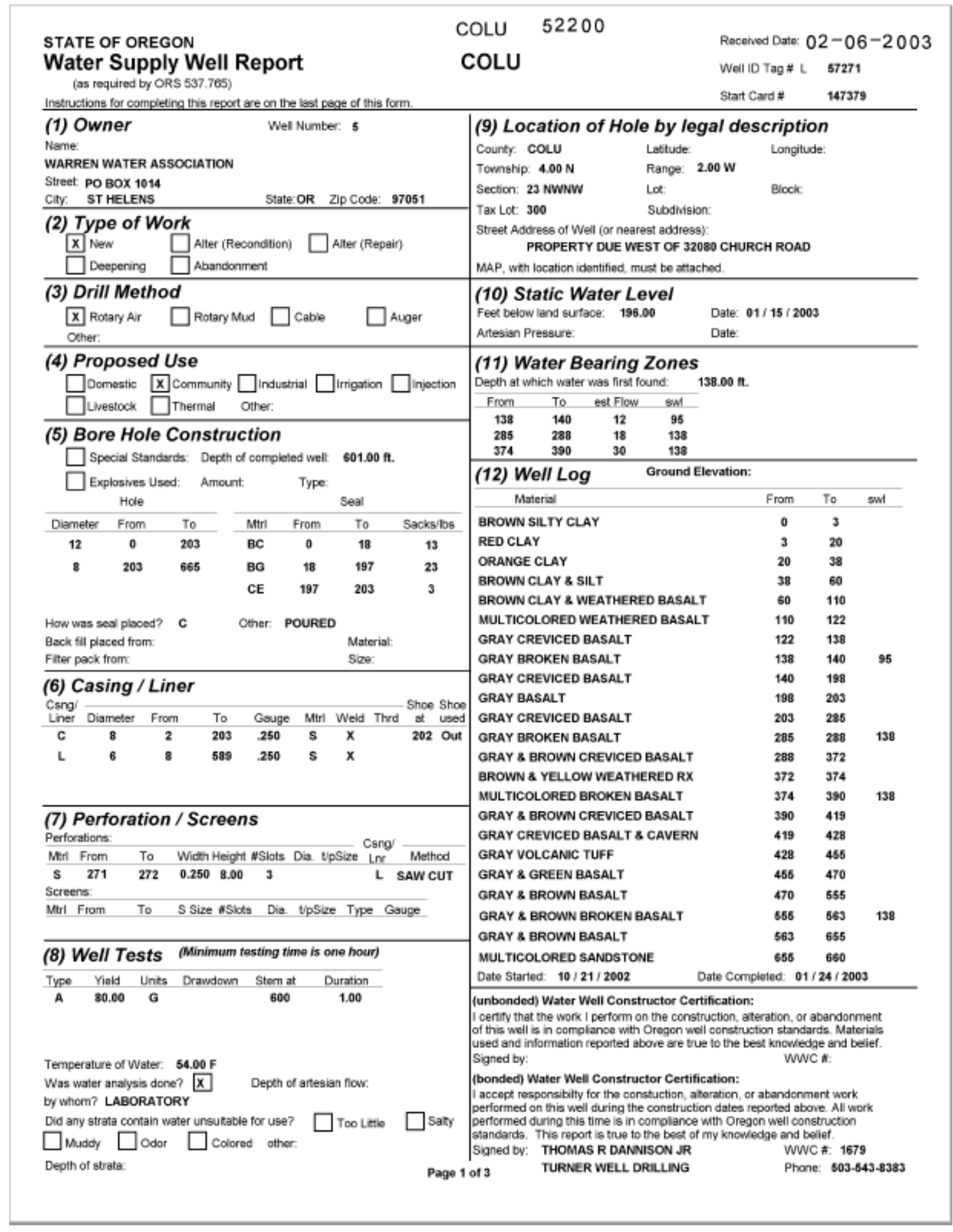

Figure 7. Example of a detailed well log.

Complete and detailed lithological description with multiple water-bearing zones, screened interval, static water level, depth to first water, and well yield. However, no physical address was given and after being field-checked, the tax lot differed from the most current assignment (Oregon Water Resource Department, 2017). 


\subsection{Determination of Lithology and Water-bearing Zones from Well Logs}

Well log reports include a section for the driller to record the type of sediment or rock encountered while drilling and the depth from the surface where each type was encountered (see Figure 7). These descriptions vary in detail and frequency of depth but generally included the type, color, texture and hardness. A GIS-layer of the surface geology (Walker and MacLeod, 1991) was added to the locator map created in ArcGIS and referenced at the geographic location to identify the surface geology at the wellhead location. Well logs also include fields for waterbearing zones, screened interval, depth to first water, and static water level.

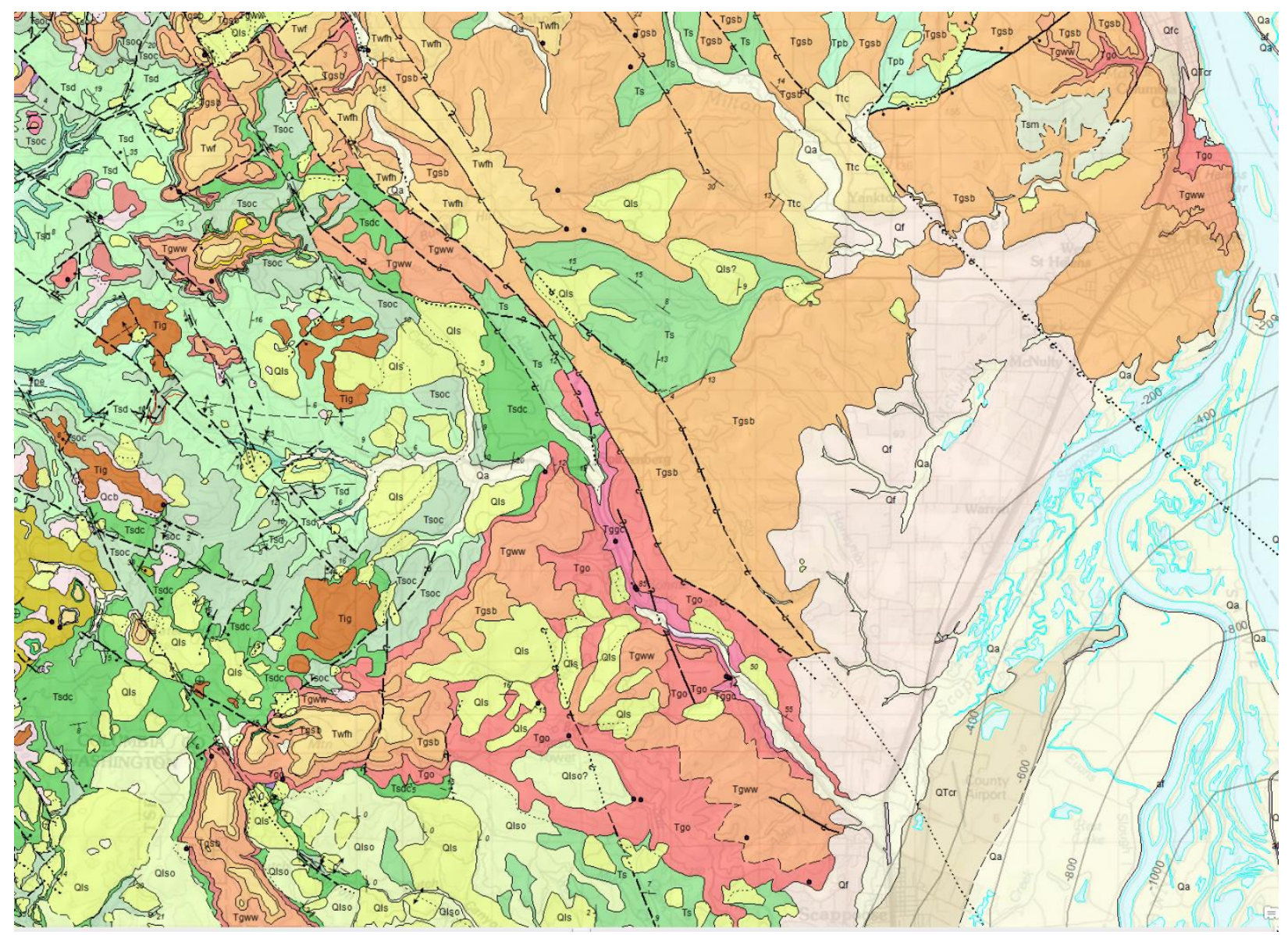

Figure 8. Preliminary Geologic Reference Map provided by (Wells et al., 2017) 
Using the driller's descriptions and published surface geology, the stratigraphy was extrapolated down to the reported hydrostratigraphic zone(s). The top of these zones were entered into the database as a "depth to water". The bottom of the water-bearing zone(s) were also recorded and a total thickness of the water-bearing zone calculated. The lithologic description and presumed geologic unit at the marked water-bearing zone was included in the database along with distinctive information from above and below.

Some key indicators that were included were reports of sandstone or mudstone below basalt units which indicated the bottom of the CRBG and transitional zone with underlying Scappoose or Pittsburg Bluff Formations and recorded lenses of seashells above gray or blue sandstone which validated the driller's geologic description as indeed sandstone and not mistakenly basalt. Such discrepancies are largely attributed to similarities in color and texture between sandstones of the Scappoose and Pittsburg Bluff Formations and weathered basalts making these lithologies difficult to distinguish from one other, especially in drill cuttings. These indicators were also key to revealing potential errors in well reports for nearby wells.

In many cases a well encountered multiple water-bearing zones. In such cases, all noted zones were included in the database from the top down as "depth to $1^{\text {st }}$ water, depth to $2^{\text {nd }}$ water, etc." and the total "water zone thickness" recorded over the entirety of all zones with an indicator of "Y" if it were multiple zones or "N" if it was one discreet zone. Although multiple water bearing zones were not often reported for sedimentary units, logs for some wells screened through the Grande Ronde Basalts recorded as many as seven discreet water-bearing zones. These discreetly separated units are thus interpreted as intra-flow zones between discrete flows, even if the lithological description was the same, as most of the members of the Grande Ronde Basalt Group consist of at least two separate flows of the same chemical composition. 
One potential source of error in determining hydrostratigraphic zones is that drillers may often be anxious to hit water in areas where water has historically been hard to locate, and record what is only trace or perched water and not actually a viable aquifer. Such instances of discontinuous or perched water zones were only discernable after cross-analyzing with nearby wells in ArcMap. This proved to be problematic when attempting to interpolate a surface of the "depth to first water" across the span of the study area using all 408 recorded well logs.

The screened interval was usually recorded in the well reports (Figure 7) as a discreet depth and length of the actual screen, often including the number of, and method of perforations cut in the screen over that interval. These were entered into the database as "Screen 1 Top" and “Screen 1 Bottom" with a calculated "Length Screen 1". Furthermore, the "screen length" of open boreholes were assumed to extend from the casing bottom or "shoe" (as top of "screened interval") to the completed bottom depth. Many of these open wells are indicated as having a "screen" length of 100 meters or more in the database.

Also included in the database associated with each screened interval is the geologic acronym associated with the geologic interpretation for that depth. Early in the study these interpretations were based largely on the driller's notes and detail of intervals, in conjunction with surface geology, which often were erroneous or incomplete. Stratigraphic patterns only began to emerge as the study progressed and the geology of some screened intervals particularly from well logs examined early in the project - are likely miss-assigned. Such errors are reflected by the well "log score" associated with the detail and completeness of the drillers $\log$ entries.

Well log scores are assigned to reflect both completeness of the record and overall confidence in the record based on detail of record and agreement with nearby wells (Table 3). 
These log scores, on a scale of 1-10, allow well logs to be queried based on the desired level of detail for analysis. Furthermore, the log score can be coupled with the locator score and other well attributes while querying to ensure the level of accuracy required for a specific analysis.

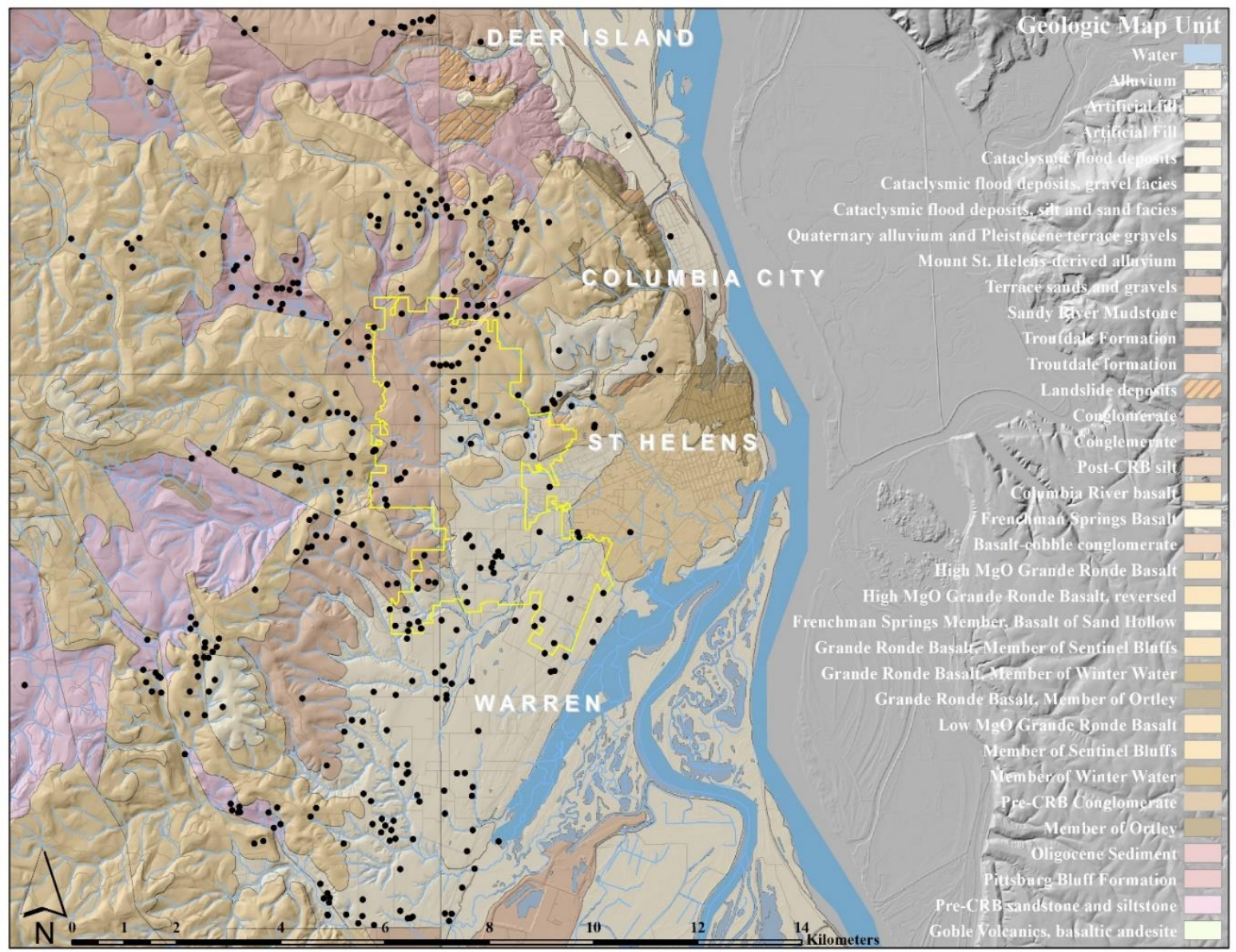

Figure 9. Oregon Geologic Digital Compilation layer (Smith, 2015). Well locations (black dots) and McNulty Water Utility Boundary (Yellow Polygon). Local variation in geologic interpretations can be seen by varying colored polygons across lines of mapped quadrangles.

\section{Table 3. Water Well Log Score}

(10) Chemically Analyzed Lithology w/well tests, screens, and zones

(9) Detailed Lithology w/well tests, screens and zones

(8) Lithology w/well tests, screens and zones

(7) Detailed Lithology w/ screens and zones

(6) Lithology w/screens and zones

(5) Detailed Lithology w/screens or zones

(4) Lithology w/screens or zones

(3) Detailed Lithology

(2) Lithology

(1) Deepened well*

Note: If a well was deepened, the previous well log was changed to (1). This was done to ensure the most recent hydrogeologic data was used for the location while preserving older data. 


\subsection{Determination of Hydraulic Parameters for Wells and Water-bearing Units}

The static water level of a well is a measure of total head (the sum of the elevation of the screen and the pressure head) at the intake (or average head for long screened intervals). Static water levels (as depths) are reported on the well logs and recorded into the database. A static water elevation is calculated as the surface elevation minus the depth to static water.

Well yields are reported per interval of water-bearing zone. A driller may report a yield of $2 \mathrm{gal} / \mathrm{min}$ and continue to drill, knowing this is sub-par for even domestic use. In such cases, several water-bearing zones may be recorded with expected yields at each zone. Once a zone of adequate yield is encountered, previous zones are sealed and the well screened so as to withdraw water from this discreet zone. However, it has been common for drillers to encounter several of these water-bearing zones of modest yield, screen all zones independently even though they are interconnected through the well casing, and report the accumulative yield on the log. This is particularly common in wells screened through multiple zones of the Columbia River Basalt Group (Figure 7).

With untargeted zones cased or sealed, the most productive interval is screened and the well is continuously pumped for no less than one hour to determine yield and associated drawdown in water level, both of which are recorded on the well log. Many cases were encountered in this study where a well that had been previously entered into the database, presumed to be completed, and drilled to a deeper depth dated only a few days or weeks after the previous date of completion. These wells were assumed to be drilled and tested, pumped for the minimum requirement of one hour, only to drawdown under normal expected operation below the screen and underperformed for the landowner resulting in further deepening to sustain continuous flow and expected rates. 


\subsection{Well Database}

\section{RESULTS \& DISCUSSION}

Well log data of 391 water wells over an area of approximately 300 square kilometers were entered into an Excel spreadsheet, which is included as an electronic attachment. The Excel spreadsheet was then imported as $\mathrm{X} / \mathrm{Y}$ data into ArcGIS software using Universal Transverse Mercator (UTM) coordinates. Well attributes were entered into the excel spreadsheet and associated with each discreet ArcMap point in the layer's attribute table.

The well log I.D number (e.g., COLU_12345), owner, and location information are the first of 67 columns contained within the spreadsheet (Digital Attachment 1). Hydrogeologic data was recorded, as available, along with the surface geology from published geologic maps of the area (Walker and MacLeod, 1991) and one yet to be published geologic map (Wells et al., 2017). Although few wells encounter gravels, a column was included to indicate such with a "Y" or "N" entry. An additional column was added to indicate if the well was constructed on a mapped landslide. Well screen intervals and the tops and bottoms of associated geologic units were entered in as depth and elevations above sea-level (note, the attached Excel file contains one sheet with metric units and one with English units).

Hydrogeologic data, including depth to water and well test results, are included with the respective dates of measurement. Depths to water and static water elevations, and water-zone tops and bottoms as depths and elevations are also included. The final columns indicate if the screen is consistent with the water-zone "Y" or " $\mathrm{N}$ " if screened outside or exclusive of the waterzone. 


\subsection{General Hydrostratigraphy}

\subsubsection{Goble Volcanic Series}

During preliminary investigations, only one well was identified with a high level of confidence to as being screened through the Goble Volcanic Series. COLU_52054, a primary utility well for Columbia City, reported alternating layers of black basalt with broken black basalt and volcanic tuff, drilled to a depth of 75 meters below sea level. The well is drilled within 100 meters of an exposed outcrop of the Ortley Member of the Grande Ronde making this well unlikely to be encountering CRBG basalts at such depth. The water-bearing zone is reported to be 34 meters thick from 45 meters below sea level with a yield of 190 Lpm (50gpm) through a $20.3 \mathrm{~cm}$ (8in) casing with only 1.2 meters drawdown after $24 \mathrm{hrs}$.

A mapped outcrop of the Goble Volcanic Series lies west of Deer Island near the mouth of Merrill Creek. Along Canaan Rd. and north of Merrill Creek five wells encountered basalt with layers of sandstone at a depth below sea level and assigned to the Goble Volcanic Series due to stratigraphic position and proximity to the mapped outcrop.

\subsubsection{Pittsburg Bluff Formation}

No wells were definitively opened through the Pittsburg Bluff Formation fitting the description of a fine-grained, olive gray sandstone. However, many well logs report massive sandstone units and were assigned to the Pittsburg Bluff Formation. Given the likely similarities in hydrogeologic characteristics, no further attempt was made to differentiate these from the Scappoose Formation. 


\subsubsection{Scappoose Formation}

Upper middle to lower hydrostratagraphic units of the Scappoose Formation are located from 15 - 65 masl with pumping rates averaging $132 \mathrm{Lpm}(35 \mathrm{gpm})$ and several above $189 \mathrm{Lmp}$ (50 gpm). A cluster of wells along Pittsburg Rd north of Riggs Rd bottom between 23 and 78 masl and their well logs report the major water bearing zone (averaging $7 \mathrm{~m}$ thick) to include blue and gray sandstone between 50 - 70 masl. Well COLU_50365 reports seamy gray/brown and dark brown sandstone bottoming at 62.5 masl, Well COLU_53806 bottoms at 23 masl and reports green and blue sandstone in the water bearing zone bellow a seam of sea shells indicating a near shore environment or fluctuations in sea level during deposition. Well COLU_1399 reports light and dark gray sandstone and bottoms out at 15 masl. This transition in color marks a change from middle to lower Scappoose. These wells indicate higher yields over $189 \mathrm{Lpm}$ (50 gpm) when screened through broken gray sandstone or sandstone with pebbles.

Wells further west report sandstone layers inter-bedded with basalts indicating the upper contact between the Scappoose Formation and units of the Columbia River Basalts. Along Canibear Rd, wells report alternating layers of multicolored sandstone inter-bedded with brown and black basalts. The water-bearing zone is 160 masl and 6 meters thick from 159 and 165 masl with well yields ranging from $19-75.7 \mathrm{Lpm}(5-20 \mathrm{gpm})$. Near the junction of Canaan and Pittsburg roads the wells bottom at 207 masl and are screened between $212-247$ masl, indicate blue-green water-bearing zone with blue red fractured basalt above. Well COLU_53863 is screened through tan sandstone with green sandstone above and bottoms at 206 masl.

The basal conglomerate of the lower Scappoose crops out along Brooks Rd. 4km east of the junction with Cater Rd. However, no contact was identified there. 


\subsubsection{Grande Ronde Basalt Formation}

The occurrence of groundwater is largely confined between discrete flows of the Grande Ronde Basalt. The intra-flow zones have an average yield of $75.7 \mathrm{Lpm}(20 \mathrm{gpm})$ and thickness of 5 meters. The Sentinel Bluffs Member has an average yield of $102 \mathrm{Lpm}(27 \mathrm{gpm})$ followed by the Ortley with an average of $79.5 \mathrm{Lpm}(21 \mathrm{gpm})$, and the Winter Water with an average of $49.2 \mathrm{Lpm}$ (13gpm). The average thickness is greatest in the Ortley at $7 \mathrm{~m}$ followed by the Sentinel Bluffs at $5 \mathrm{~m}$, and the Winter Water at $4.3 \mathrm{~m}$.

Wells screened through multiple water-bearing zones in the Grande Ronde have an average yield of $268.8 \mathrm{Lpm}$ (71gpm) and combined average thickness of 47m. Although more productive when open through multiple hydrostratigraphic units (Figure 10), this method of withdrawal can lower the static level having a detrimental effect to nearby wells screened only through upper units. Of the 139 wells screened through the Grande Ronde Basalt, 67 are reported as being screened through multiple zones.

The Grande Ronde aquifers are largely controlled by structural features. The southeast trending syncline oriented along Milton Creek has the greatest influence on regional flow direction (Figure 13). From the north ridge above Merrill Creek groundwater flow is primarily to the south, from the ridge above North Scappoose and Alder Creeks, to the northeast.

\subsubsection{Alluvial Deposits}

Predominantly sands and gravels, shallow alluvium deposits produce withdraw rates averaging $105 \mathrm{Lpm}$ (27.6 gpm) at 55 domestic well locations across the span of Warren Bench. Four large public utility wells also withdraw from these alluvium deposits, two west of the town of Warren and two north of St Helens near the Columbia River channel. 


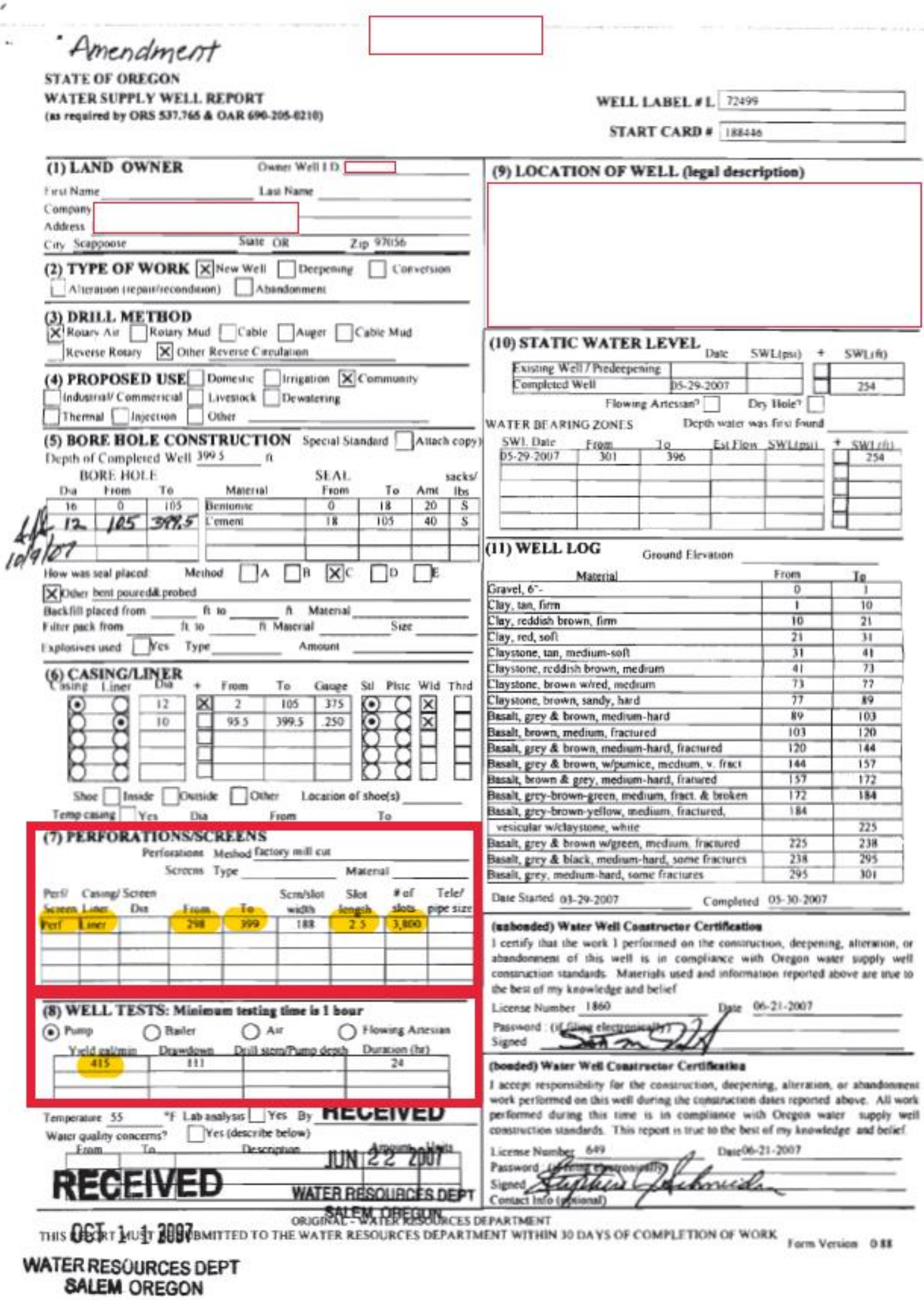

Figure 10. Example of a Well Open through Multiple Zones 


\subsection{Well Yields}

Table 4. Average Hydrostratigraphic Well Yields

\begin{tabular}{lcrrr}
\hline $\begin{array}{c}\text { Hydrogeologic } \\
\text { Zone(s) }\end{array}$ & $\begin{array}{c}\text { Well } \\
\text { Count }\end{array}$ & \multicolumn{3}{c}{ Well Yield (gpm) } \\
Mean & Minimum & Maximum \\
\hline Alluvium & 59 & 39 & 6 & 300 \\
Sentinel Bluffs* & 49 & 35 & 5 & 250 \\
Winter Water* & 24 & 65 & 7 & 450 \\
Ortley* & 66 & 46 & 3 & 415 \\
Grouse Creek* & 10 & 24 & 4 & 120 \\
Scappoose & 56 & 35 & 0 & 500 \\
Pittsburg Bluff & 117 & 26 & 0 & 400 \\
Goble Series & 10 & 34 & 1 & 90 \\
\hline *Includes wells
\end{tabular}

*Includes wells screened through multiple entra-flow zones

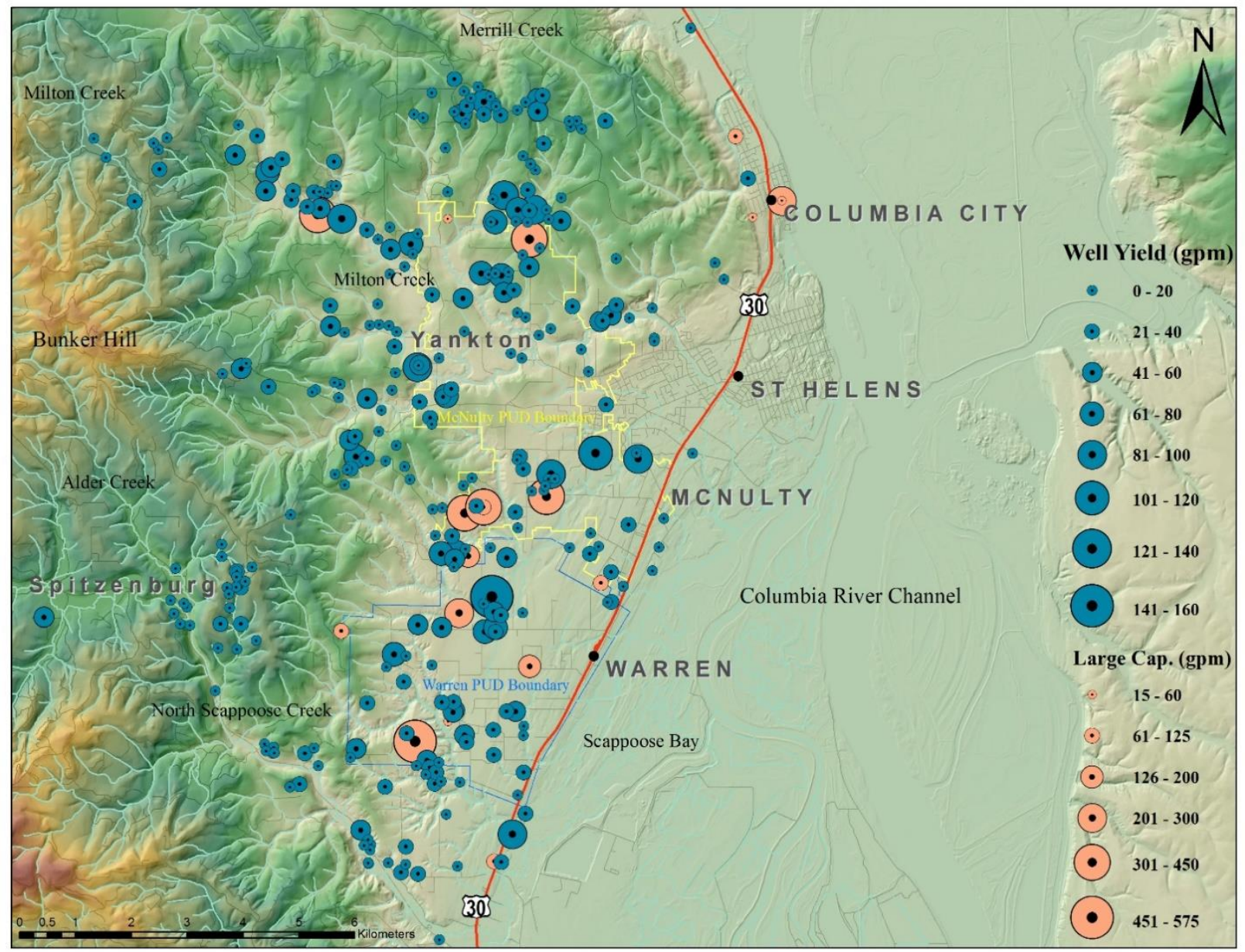

Figure 11. Well Yields in gallons per minute, domestic (blue) and public (red) wells. 


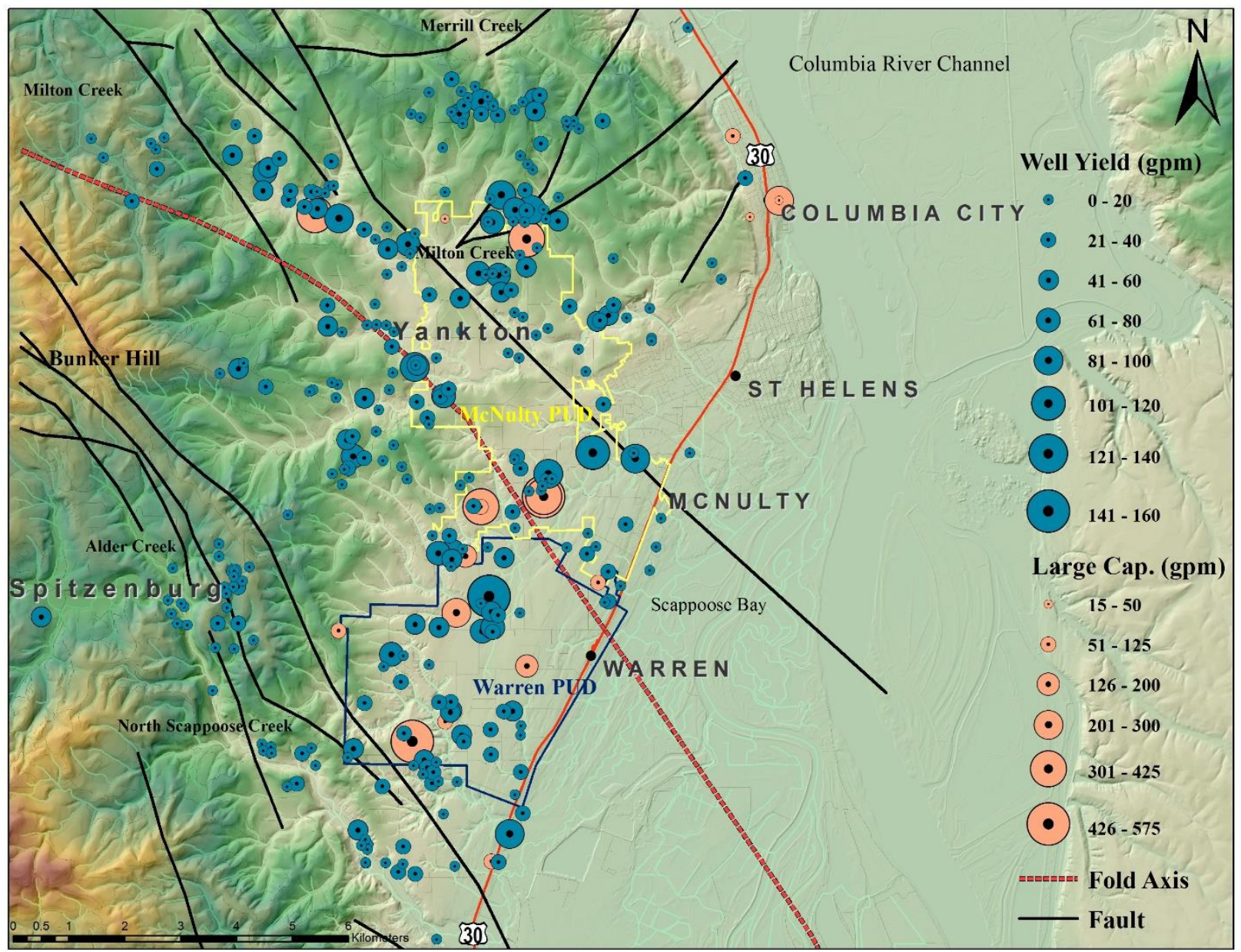

Figure 12 Well Yield and the Correlation of Structural Influence

Wells drilled near the axis of the syncline, from the towns of Warren and McNulty northwest near Milton and Dart Creeks, typically have the greatest yields. Exceptions are wells open through several intra-flow zones of the CRBG members such as COLU_53422, screened through 101 m of basalt, and well COLU_53400, located north of St Helens at 25 meters above sea level and within $220 \mathrm{~m}$ of the Columbia River Channel.

Regional and widespread faulting has likely juxtaposed Columbia River Basalts with lower sedimentary members, dissecting the lateral inter-connectivity of water bearing zones (Figure 5) and potentially "damming" groundwater flow from higher elevation behind faults. 
This effect may be seen in the wells north of Milton Creek and the town of Yankton at the convergence of two presumed faults. As a result, water-bearing zones within the study area are largely of limited capacity and transmissivity over great distance is impeded.

\subsection{Static Water Level \& Depth to Water Maps}

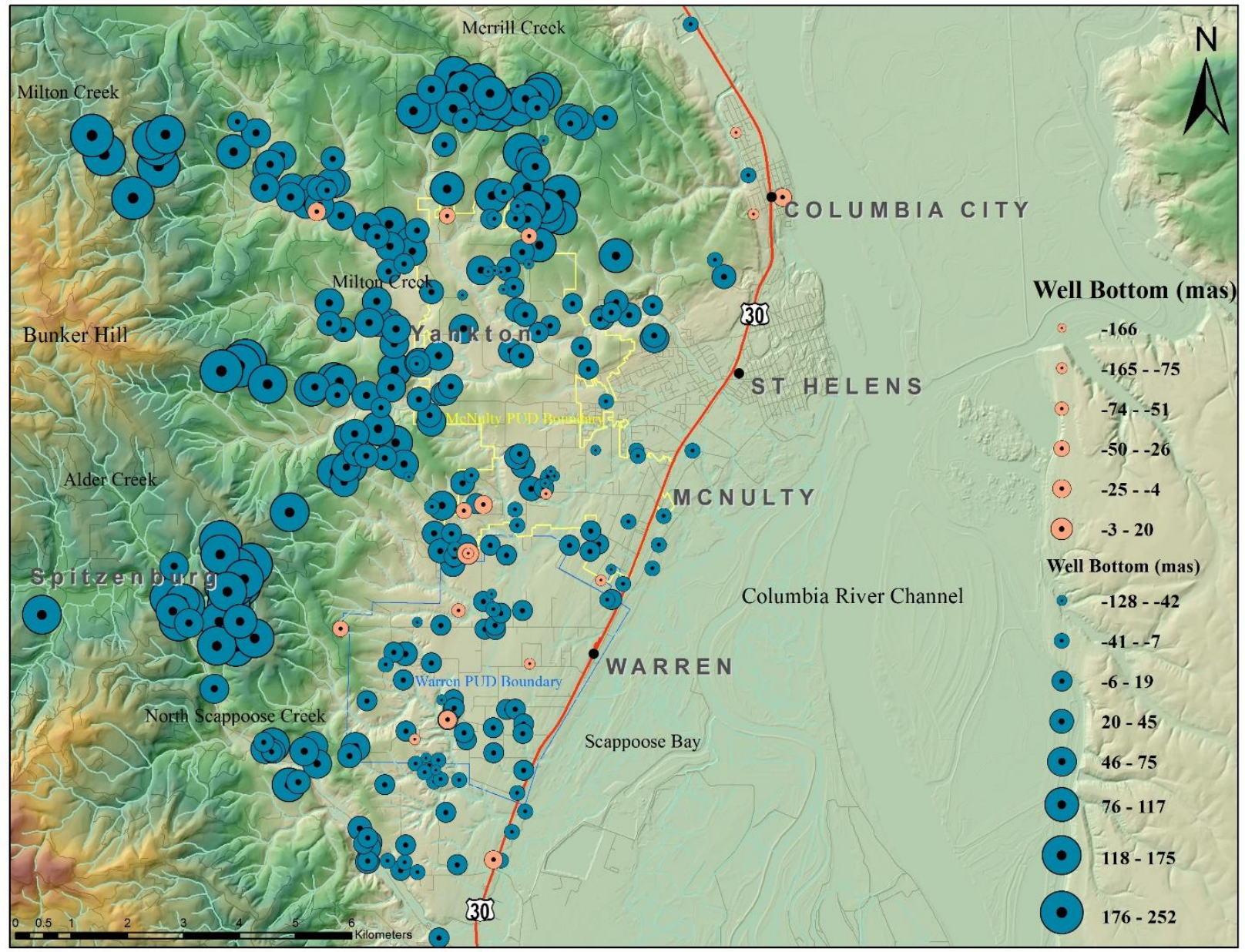

Figure 13. Well Bottom in meters above sea-level, domestic (blue) and public (red) wells.

Depth to water increases toward the rising limbs, north and south of the syncline axis trending through the town of Warren and south of the town of Yankton (Figure 12), and with rising elevation from the Columbia River channel (Figure 13). Northeast along Cater Road, west along Bunkerhill and Pittsburg roads, and to the north along Axel Smith Road, well bottoms are at their highest elevations, generally above 60 masl and with depths averaging $>78$ meters below the surface. 
Wells drilled on the "Warren Bench" are generally drilled to depths less than 60 meters and extract groundwater from shallow alluvium aquifers. Large production wells, however, are drilled to an average depth of 140 meters and extract groundwater from intra-flow zones of the Columbia River Basalts well below sea level.

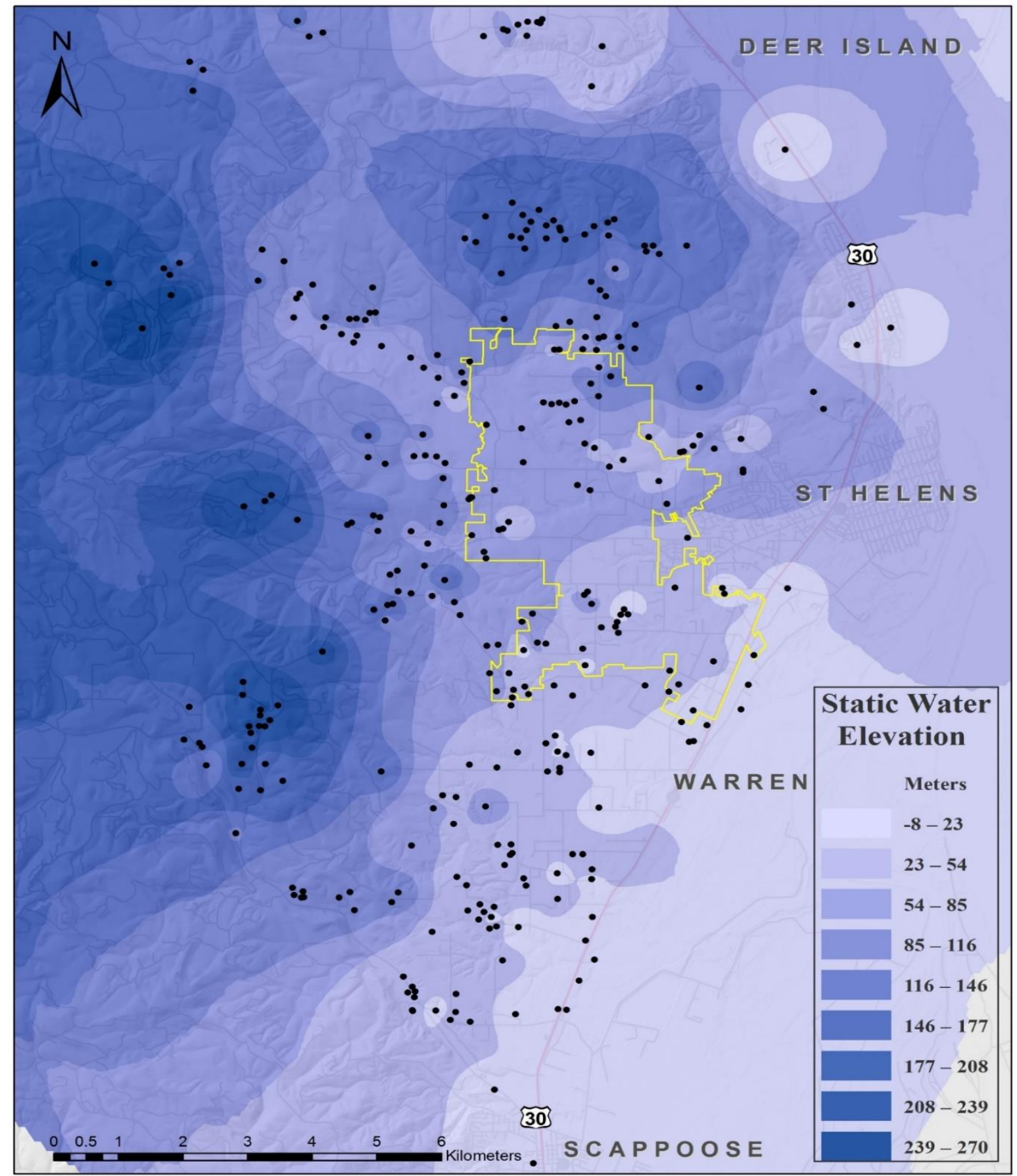

Figure 14. Preliminary Map of the Potentiometric Surface. Aquifers undifferentiated. 


\section{CONCLUSIONS}

In this study five distinct hydrostratigraphic units were identified: alluvial deposits within creek channels and on the "Warren Bench" deposited by the Columbia River and glacial outburst floods from lake Missoula, intra-flow zones of the Columbia River Basalt members: the Sentinel Bluffs, Winter Water, Ortley, and of lesser significance, the Grouse Creek, members of the Grande Ronde Formation, the terrestrial and shallow marine sediments of the Scappoose and Pittsburg Bluff Formations, and of least significance, the Goble Series only found at great depth or north of the study area near the city of Deer Island (Table 5).

On average, the most productive water bearing zones are interflow zones within the Columbia River Basalts. The Sentinel Bluffs, Winter Water, and Ortley, which have an average discrete intra-flow thickness of $5 \mathrm{~m}$ and groundwater well yield of $75.5 \mathrm{Lpm}$ (20gpm). Although some wells screened through the Scappoose and Pittsburg Bluff Formations provide adequate yields, these are inconsistent over even short distances and less transmissive than the intra-flow zones of the Columbia River Basalts.

The occurrence of water bearing zones, particularly those of the Columbia River Basalts, are largely controlled by structural deformation and paleo-topography, including canyon incisions and infilling by ancestral Columbia River gravels. Wells open through multiple intraflow zones are more productive, however by equalizing the pressure head through multiple intraflow zones, withdraw rates may exceed the capacity of discrete zones. This tends to have detrimental effect to nearby wells extracting groundwater from only a single discreet zone and may require deepening as capacity of previously discrete zones becomes exceeded. 
Table 5. Summary of Hydrogeologic Average Characteristics (see Appendix 2 for full table.)

\begin{tabular}{lcccccc}
\hline \hline $\begin{array}{c}\text { Hydrogeologic } \\
\text { Zone(s) }\end{array}$ & $\begin{array}{c}\text { Well } \\
\text { Count }\end{array}$ & $\begin{array}{c}\text { Well Yield } \\
(\mathrm{Lpm})\end{array}$ & $\begin{array}{c}\text { Well } \\
\text { Drawdown }(\mathrm{m})\end{array}$ & $\begin{array}{c}\text { Well Bottom } \\
(\mathrm{masl})\end{array}$ & $\begin{array}{c}\text { Aquifer Top } \\
(\text { masl) }\end{array}$ & $\begin{array}{c}\text { Aquifer } \\
\text { Thickness (m) }\end{array}$ \\
\hline Alluvium & 59 & 148 & 14 & 7 & 25 & 16 \\
Sentinel Bluffs & 49 & 133 & 8 & 45 & 67 & 19 \\
Winter Water & 24 & 245 & - & 9 & 45 & 29 \\
Ortley & 66 & 174 & 40 & 24 & 59 & 30 \\
Grouse Creek & 10 & 90 & - & 50 & 70 & 17 \\
Scappoose & 56 & 134 & 22 & 79 & 31 & 13 \\
Pittsburg Bluff & 117 & 97 & 46 & 48 & 76 & 17 \\
Goble Series & 10 & 127 & - & -31 & -4 & 10 \\
$\quad$ (-) Insufficient data & & & & & &
\end{tabular}




\section{References}

Beeson, M. H., 1989, The Columbia River Basalt Group in western Oregon; geologic structures and other factors that controlled emplacement patterns. In S. a. Reidel, GSA Special Paper 239: Volcanism and Tectonism in the Columbia River Flood-Basalt Province (Vol. Vol. 112, pp. 223 - 246). Boulder: Geological Society of America.

Columbia County, 2017, Columbia County Assessor's Office GIS Data Files, The Values are the current Certified Values. Retrieved 2017, from http://www.co.columbia.or.us/departments/assessors-office-main/gis-data

Eriksson, A., 2002, Stratigraphy, Structure, and Natural Gas Potential of the Tertiary Sedimentary and Volcanic Units, Clatskanie 7.5-minute Quadrangle, Northwest Oregon [M.S.: Oregon State University, 235 p.

Evarts, R. C., 2002a, Geologic map of the Deer Island Quadrangle, Columbia County, Oregon and Cowlitz County, Washington. U.S. Geological Survey Miscellaneous Field Studies Map MF-2392.

Evarts, R. C., 2004, Geologic Map of the Saint Helens Quadrangle, Columbia County Oregon, and Clark and Cowlitz Counties, Washington. U.S. Geological Survey Scientific Investigations Map 2834.

Evarts, R. H., 2002b, Complex right lateral faulting at the northern end of the Portland Basingeologic, aeromagnetic, and paleomagnetic evidence. Geological Society of America Abstracts with Program, v. 34, no. 5.

Evarts, R. C., O'Connor, J. E., Wells, R. E., and Madin, I. P., 2009, The Portland Basini: A (big) river runs through it: GSA Today, v. 19, p. 4-10.

Kelty, K. B., 1981, Stratigraphy, lithofacies and environment of deposition of the Scappoose Formation in Central Columbia County, Oregon: Portland Oreg. Portland State University, M.S. thesis.

Madin, I. A., 2008, Preliminary Geologic Map of The Dixie Mountain 7.5' Quadrangle, Columbia, Multnomah, and Washington Counties, Oregon. Oregon Department of Geology and Mineral Industries Open File Report O-08-07.

Moore, E. J., 1976, Oligocene Marine Mollusks from the Pittsburg Bluff Formation in Oregon. U.S. Department of the Interior, U.S. Geological Survey. U.S. Geological Survey Professional Paper 922.

McPhee, D.K., Langenheim, V.E., Wells, R.E., Blakely, R.J., 2014, Tectonic evolution of the Tualatin basin, northwest Oregon, as revealed by inversion of gravity data. Geosphere; 10 (2): 264-275. doi: https://doi.org/10.1130/GES00929.1

Niem, A. R., \& Van Atta, R. O., 1973, Cenozoic Stratigraphy of Northwestern Oregon and Adjacent Southwestern Washington. Geologic Field Trips in Northern Oregon and Southern Washington, 75-135. 
Oregon Water Resources Department, 2017, (O. W. Department, Producer) Retrieved 2017 , from http://www.oregon.gov/OWRD/pages/index.aspx

Reidel, S. P., Tolan, T. L., Hooper, P. R., \& and Beesen, M. H. (1989). The Grande Ronde Basalt, Columbia River Basalt Group; Stratigraphic descriptions and correlations in Washington, Oregon, and Idaho. In S. a. Reidel, GSA Special Paper 239: Volcanism and Tectonism in the Columbia River Flood-Basalt Province (pp. 1-20). Boulder: Geological Society of America.

Smith, R. L., 2015, Oregon Geologic Data Compilation release 6 (OGDC6). Oregon Geologic Digital Compilation - Release 6. Retrieved from http://www.oregongeology.org

Swanson, D. W. (1979). Revision in the Stratigraphic Nomenclature of the Columbia River Basalt Group. U.S. Geological Survey Bulletin 1457-G.

Tolan, T. L., Reidel, S. P., Anderson, J. L., Lindsey, K. A., Burt, W., \& Martin, B. S. (2009). An introduction to the stratigraphy, structural geology, and hydrogeology of the Columbia River Flood-Basalt Province: A primer for the GSA Columbia River Basalt Group field trips. In J. D. O'Connor, Volcanoes to Vineyards: Geologic Field Trips Through the Dynamic Landscape of the Pacific Northwest (pp. 599-643). Boulder: Geological Society of America Field Guide 15.

Van Atta, R.O., and Kelty, K.B.,1985, Scappoose Formation, Columbia County, Oregon: New Evidence of Age and Relation to Columbia River Basalt Group. The Ammerican Association of Petroleum Geologists Bulletin v 69(5), 688-698.

Van Atta, R. O., 1971, Sedimentary Petrology of some Tertiary Formations, Upper Nehalem River Basin, Oregon. Doctoral Dissertation, Oregon State University. http://ir.library.oregonstate.edu/concern/graduate_thesis_or_dissertations/pk02cf22r

Wagner, D. L.,2013, Hydrogeologic Characterization of Dutch Canyon, Scappoose, Oregon. M.S. Thesis, Portland State University.

Walker G.W., and MacLeod, N.,1991, Geologic Map of Oregon. (USGS, Editor)

Wells, R. E.,2009, The Columbia River Basalt Group -- From the gorge to the sea. In J. D. O'Conner, Volcanoes to Vineyards: Geologic Field Trips Through the Dynamic Landscape of the Pacific Northwest (pp. 737-774). Boulder: Geological Society of America Field Guide 15.

Wells, R. E. Haugerud, R.A., et al., 2017, Geologic Map of the Greater Portland Metropolitan Area, Oregon and Washington. U.S. Geological Survey Scientific Investigations Map. Retrieved 2017

Wells, R. E.,1998, Fore-arc migration in Cascadia and its neotectonic significance. Geology, $v$. 26(8), 759-762.

Wells, R. E., 2014, Preliminary geologic map of the eastern Willapa Hills, Cowlitz, Lewis, and Wahkiakum Counties, Washington.

Wells, R. E., Bukry, D., Friedman, R., Pyle, D., Duncan, R., Haeussler, P., and Wooden, J., 2014, Geologic history of Siletzia, a large igneous province in the Oregon and 
Washington Coast Range: Correlation to the geomagnetic polarity time scale and implications for a long-lived Yellowstone hotspot: Geosphere, v. 10, p. 692-719.

Wells, R. E., Snavely Jr., P. D., MacLeod, N. S., Kelly, M. M., and Parker, M. J., 1994, Geologic Map of the Tillamook Highlands, Northwest Oregon Coast Range.

Wells, R. E., Weaver, C. S., and Blakley, R. J., 1998, Fore-arc migration in Cascadia and its neotectonic significane: Geology, v. 26, p. 759-762.

Wilkinson, W. D., L. W., \& Baldwin, E. M. (1946). Geology of the St. Helens quadrangle, Oregon: Scale 1:62,500. Oregon Department of Geology and Mineral Industries Bulletin 31 . 
Digital Attachment 1. Warren Bench Water Well Database Spreadsheet 


\title{
Appendix 1. Chemical Composition of Select Members of the Columbia River Basalts
}

\author{
DESCRIPTION OF SELECT STRATIGRAPHIC UNITS OF THE GRANDE RONDE AND WANAPUM FORMATIONS
}

\begin{tabular}{|c|c|c|c|c|c|c|c|c|c|c|c|c|}
\hline Formation & \multicolumn{3}{|c|}{ WANAPUM BASALT } & \multicolumn{9}{|c|}{ GRANDE RONDE BASALT } \\
\hline Member & \multicolumn{3}{|c|}{ Frenchman Springs } & \multicolumn{3}{|c|}{ Sentinel Bluffs } & \multicolumn{3}{|c|}{ Winter Water } & \multicolumn{3}{|c|}{ Ortley } \\
\hline Unit & \multicolumn{12}{|c|}{ Basalt of Sand Hollow } \\
\hline Magnetic Polarity & \multicolumn{3}{|c|}{ Normal } & \multicolumn{3}{|c|}{$\operatorname{Normal}\left(\mathrm{N}_{2}\right)$} & \multicolumn{3}{|c|}{$\operatorname{Normal}\left(\mathrm{N}_{2}\right)$} & \multicolumn{3}{|c|}{$\operatorname{Normal}\left(\mathrm{N}_{2}\right)$} \\
\hline Number of flows & \multicolumn{3}{|c|}{3} & \multicolumn{3}{|c|}{$\sim 5$} & \multicolumn{3}{|c|}{2} & \multicolumn{3}{|c|}{$\sim 6$} \\
\hline Composition & $\overline{\mathrm{X}}$ & $\sigma$ & $\mathrm{N}$ & $\bar{x}$ & $\sigma$ & $\mathrm{N}$ & $\bar{x}$ & $\sigma$ & $\mathrm{N}$ & $\bar{x}$ & $\sigma$ & $\mathrm{N}$ \\
\hline $\mathrm{SiO}_{2}$ & 51.82 & 0.49 & 55 & 53.99 & 0.67 & 63 & 55.54 & 0.42 & 31 & 55.92 & 0.60 & 36 \\
\hline $\mathrm{Al}_{2} \mathrm{O}_{3}$ & 14.58 & 0.33 & 55 & 15.26 & 0.36 & 63 & 14.88 & 0.17 & 31 & 15.15 & 0.19 & 36 \\
\hline $\mathrm{TiO}_{2}$ & 2.91 & 0.07 & 55 & 1.97 & 0.10 & 63 & 2.21 & 0.05 & 31 & 2.02 & 0.05 & 36 \\
\hline $\mathrm{FeO}$ & 13.79 & 0.51 & 55 & 11.05 & 0.60 & 63 & 11.93 & 0.61 & 31 & 10.85 & 1.74 & 36 \\
\hline $\mathrm{MnO}$ & 0.22 & 0.02 & 55 & 0.21 & 0.03 & 63 & 0.21 & 0.01 & 31 & 0.20 & 0.01 & 36 \\
\hline $\mathrm{CaO}$ & 8.18 & 0.26 & 55 & 8.54 & 0.33 & 63 & 7.06 & 0.20 & 31 & 7.06 & 0.18 & 36 \\
\hline $\mathrm{MgO}$ & 4.42 & 0.26 & 55 & 4.66 & 0.26 & 63 & 3.55 & 0.19 & 31 & 3.61 & 0.12 & 36 \\
\hline $\mathrm{K}_{2} \mathrm{O}$ & 1.19 & 0.14 & 55 & 1.10 & 0.21 & 63 & 1.64 & 0.15 & 31 & 1.77 & 0.17 & 36 \\
\hline $\mathrm{Na}_{2} \mathrm{O}$ & 2.20 & 0.37 & 55 & 2.39 & 0.35 & 63 & 2.44 & 0.16 & 31 & 2.61 & 0.37 & 36 \\
\hline $\mathrm{P}_{2} \mathrm{O}_{5}$ & 0.48 & 0.02 & 55 & 0.30 & 0.02 & 63 & 0.34 & 0.02 & 31 & 0.31 & 0.02 & 36 \\
\hline $\mathrm{Cr}$ & 37 & 4.5 & 38 & 43 & 3 & 18 & 16 & 0.4 & 6 & 15 & 3 & 4 \\
\hline $\mathrm{Ba}$ & 538 & 16 & 7 & 480 & 31 & 17 & 625 & 44 & 6 & 708 & 92 & 4 \\
\hline Lithology & \multicolumn{3}{|c|}{$\begin{array}{l}\text { Sparsely to } \\
\text { abundantly phyric } \\
\text { with plagioclase } \\
\text { phenocryst that } \\
\text { commonly range } \\
\text { from } 0.3 \text { to } 3 \mathrm{~cm} \text { in } \\
\text { size. Groundmass is } \\
\text { fine to coarse } \\
\text { grained and is } \\
\text { sparsely } \\
\text { microphyric with } \\
\text { plagioclase } \\
\text { microphenocrysts. }\end{array}$} & \multicolumn{3}{|c|}{$\begin{array}{l}\text { Rarely to } \\
\text { abundantly phyric } \\
\text { with plagioclase } \\
\text { phenocrysts that } \\
\text { comonly range } \\
\text { from } 0.2 \text { to } 0.7 \mathrm{~cm} \\
\text { in size. } \\
\text { Groundmass is } \\
\text { fine to medium } \\
\text { grained } \\
\text { microphyric with } \\
\text { tabular and } \\
\text { acicular } \\
\text { plagioclase } \\
\text { microphenocrysts. }\end{array}$} & \multicolumn{3}{|c|}{$\begin{array}{l}\text { Sparsely to abundantly } \\
\text { phyric with plagioclase } \\
\text { phenocrysts/ } \\
\text { glomerocrysts that } \\
\text { typically range from } 0.1 \\
\text { to } 0.3 \mathrm{~cm} \text { in size. }\end{array}$} & \multicolumn{3}{|c|}{$\begin{array}{l}\text { Aphyric to rarely } \\
\text { plagioclase phyric. } \\
\text { Groundmass is typically } \\
\text { fine grained and not } \\
\text { microphyric. }\end{array}$} \\
\hline References & \multicolumn{3}{|c|}{$\begin{array}{l}\text { Beeson and others } \\
\text { (1985) }\end{array}$} & \multicolumn{3}{|c|}{$\begin{array}{c}\text { Tolan (1982); } \\
\text { Anderson (1978); } \\
\text { Reidel et al. } \\
\text { (1989) }\end{array}$} & \multicolumn{3}{|c|}{$\begin{array}{c}\text { Hoffman (1981); Tolan } \\
\text { (1982); Reidel et al. } \\
\text { (1989) }\end{array}$} & \multicolumn{3}{|c|}{ Reidel et al. (1989) } \\
\hline
\end{tabular}




\section{Appendix 2. Hydrogeologic Characteristics}

\begin{tabular}{|c|c|c|c|c|c|c|c|c|c|c|c|c|c|c|c|c|}
\hline \multirow{2}{*}{$\begin{array}{c}\text { Hydrogeologic } \\
\text { Zone(s) }\end{array}$} & \multirow{2}{*}{$\begin{array}{c}\text { Well } \\
\text { Count }\end{array}$} & \multicolumn{3}{|c|}{ Well Yield (Lpm) } & \multicolumn{3}{|c|}{ Well Drawdown (m) } & \multicolumn{3}{|c|}{ Well Bottom (masl) } & \multicolumn{3}{|c|}{ Aquifer Top (masl) } & \multicolumn{3}{|c|}{ Aquifer Thickness (m) } \\
\hline & & Mean & Min & $\operatorname{Max}$ & Mean & Min & $\operatorname{Max}$ & Mean & Min & $\operatorname{Max}$ & Mean & Min & $\operatorname{Max}$ & Mean & Min & $\operatorname{Max}$ \\
\hline Alluvium & 59 & 148 & 23 & 1136 & 14 & 2 & 36 & 7 & -97 & 62 & 25 & -20 & 67 & 16 & $\mathbf{0}$ & 51 \\
\hline Discrete Zone & 44 & 130 & 23 & 757 & 11 & 2 & 26 & 9 & -97 & 62 & 27 & -20 & 67 & 15 & 0 & 51 \\
\hline Multiple Zones & 14 & 207 & 42 & 1136 & 23 & 10 & 36 & 1 & -21 & 15 & 20 & -2 & 45 & 19 & 9 & 33 \\
\hline Sentinel Bluffs & 49 & 133 & 19 & 946 & 8 & 2 & 18 & 45 & -108 & 251 & 67 & -37 & 268 & 19 & $\mathbf{0}$ & 133 \\
\hline Discrete Zone & 34 & 102 & 19 & 379 & 32 & 6 & 18 & 52 & -50 & 251 & 61 & -37 & 258 & 5 & 0 & 12 \\
\hline Multiple Zones & 15 & 198 & 26 & 946 & - & 2 & - & 31 & -108 & 222 & 80 & 16 & 268 & 48 & 13 & 133 \\
\hline Winter Water & 24 & 245 & 26 & 1703 & - & 31 & - & 9 & -85 & 207 & 45 & -32 & 247 & 29 & $\mathbf{0}$ & 103 \\
\hline Discrete Zone & 10 & 50 & 26 & 102 & - & 31 & - & 67 & -1 & 207 & 79 & 11 & 247 & 4 & 0 & 12 \\
\hline Multiple Zones & 14 & 370 & 45 & 1703 & - & - & - & -32 & -85 & 38 & 20 & -32 & 64 & 47 & 9 & 103 \\
\hline Ortley & 66 & 174 & 9 & 1571 & 40 & 22 & 87 & 24 & -128 & 242 & 59 & -36 & 257 & 30 & 2 & 150 \\
\hline Discrete Zone & 28 & 78 & 9 & 303 & 53 & 22 & 87 & 35 & -47 & 242 & 47 & -35 & 257 & 7 & 2 & 24 \\
\hline Multiple Zones & 38 & 245 & 19 & 1571 & 33 & 23 & 45 & 16 & -128 & 186 & 68 & -36 & 216 & 46 & 8 & 150 \\
\hline Grouse Creek & 10 & 90 & 15 & 454 & - & 10 & - & 50 & -96 & 151 & 70 & -52 & 159 & 17 & $\mathbf{0}$ & 82 \\
\hline Discrete Zone & 7 & 33 & 15 & 57 & - & 10 & - & 78 & 10 & 151 & 84 & 11 & 159 & 4 & 0 & 9 \\
\hline Multiple Zones & 3 & 223 & 79 & 454 & - & - & - & -17 & -96 & 36 & 36 & -52 & 118 & 46 & 21 & 82 \\
\hline Scappoose & 56 & 134 & 1 & 1893 & 22 & 3 & 55 & 79 & -81 & 222 & 101 & -56 & 255 & 13 & $\mathbf{0}$ & 63 \\
\hline Discrete Zone & 41 & 70 & 1 & 284 & 25 & 3 & 55 & 84 & -81 & 222 & 101 & -56 & 255 & 7 & 0 & 52 \\
\hline Multiple Zones & 15 & 310 & 11 & 1893 & 19 & 12 & 25 & 66 & -33 & 179 & 101 & -17 & 225 & 28 & 6 & 63 \\
\hline Pittsburg Bluff & 117 & 97 & 1 & 1514 & 46 & 5 & 139 & 48 & -110 & 206 & 76 & -62 & 216 & 17 & $\mathbf{0}$ & 117 \\
\hline Discrete Zone & 89 & 97 & 1 & 1514 & 42 & 5 & 139 & 51 & -88 & 206 & 72 & -62 & 216 & 8 & 0 & 79 \\
\hline Multiple Zones & 28 & 97 & 7 & 379 & 54 & 8 & 108 & 39 & -110 & 165 & 90 & 19 & 175 & 44 & 2 & 117 \\
\hline Goble Series & 10 & 127 & 2 & 341 & - & - & 1 & -31 & -90 & 122 & -4 & -61 & 107 & 10 & $\mathbf{0}$ & 34 \\
\hline Discrete Zone & 9 & 120 & 2 & 341 & - & - & 1 & -26 & -90 & 122 & -3 & -61 & 107 & 7 & 0 & 30 \\
\hline Multiple Zones & 1 & - & & 189 & - & - & - & - & - & -75 & - & -11 & & - & - & 34 \\
\hline
\end{tabular}

(-) Insufficient data 